\title{
Os impactos do beneficiamento da ardósia em papagaio
}

\section{The impacts of slate processing in papagaio}

DOI: 10.46814/lajdv3n6-013

Recebimento dos originais: 01/10/2021

Aceitação para publicação: 24/11/2021

\author{
Willian Melgaço Vasconcelos \\ Universidade Federal dos Vales do Jequitinhonha e Mucuri - UFVJM \\ Campus JK. Rodovia MGT 367 - Km 583, n 5000. Alto da Jacuba Diamantina/MG CEP 39100- \\ 000 . \\ E-mail: willian.melgaco@ufvjm.edu.br
}

\section{RESUMO}

A mineração é uma atividade importante para o Brasil, haja vista que fornece matéria prima para a indústria em vários setores produtivos, como, por exemplo, na produção de cerâmicas ou cimento, além da produção de rochas ornamentais. Partindo desta premissa, a cidade mineira de Papagaios foi considerada, no início do ano 2000, capital nacional da ardósia, cabendo à mesma a organização de feiras e/ou exposições no ramo da extração, logo, o municícpio foi fonte de subsídio para realização desta pesquisa, sendo possível revelar o perfil de uma comunidade inserida num ambiente extrativista e beneficiador. O objetivo do estudo foi identificar os impactos ambientais causados pelo beneficiamento da ardósia no município de Papagaios em Minas Gerais. Do ponto de vista da saúde humana, foram correlacionadas doenças respiratórias. Para tanto, foi necessário acompanhar o beneficiamento da ardósia. Buscou-se também caracterizar o processo de legislação ambiental. Portanto, a partir da realização da pesquisa em voga, discutiu-se se o beneficiamento da ardósia, fazendo inferências ao meio ambiente, saúde e sociedade. Além da revisão bibliográfica, o presente trabalho se consolidou em três etapas: a primeira consitiu na aplicação de um questionário na comunidade supramencionada; a segunda pautou-se na execução de uma atividade intitulada "Saída de Campo", em parceria com alunos do sétimo ano da Escola Estadual "Renato Filgueiras", para a aquisição de material fotográfico em trechos do córrego da "Estribeira". E a terceira e etapa buscou acompanhar o processo de beneficiamento da ardósia de uma empresa local, além das visitas a postos de saúde de Papagaios. Os resultados da pesquisa mostram que há denuncia dos impactos ambientais, que o córrego da Estribeira recebe efluentes industriais, e que não há associação entre tais resíduos e a empresa, cujo processo produtivo foi acompanhado. Outro aspecto importante apresentado como resultado é a associação entre a silicose e a atividade beneficiadora e de extração.

Palavras-chave: Mineração, Ardósia, Beneficiamento, Papagaios, Córrego da "Estribeira".

\begin{abstract}
Mining is an important activity for Brazil, since it provides raw material for the industry in several productive sectors, such as in the production of ceramics or cement, as well as the production of ornamental rocks. Based on this premise, the mining city of Papagaios was considered, at the beginning of the year 2000, national capital of the slate, being the same the organization of fairs and / or expositions in the branch of the extraction, soon, the municipality was source of subsidy for accomplishment of this Research, and it is possible to reveal the profile of a community inserted in an extractive and benefiting environment. The objective of the study was to identify the environmental impacts caused by the slate processing in the municipality of Papagaios. From the point of view of human health, respiratory diseases was correl. For that, it was necessary to accompany the processing
\end{abstract}


of the slate. It was also to characterize the process of environmental legislation. Therefore, from the realization of the research in vogue, it was discussed whether the beneficiation of the slate, making inferences to the environment, health and society. In addition to the bibliographic review, the present study was consolidated in three stages: the first one consisted in the application of a questionnaire in the aforementioned community; The second was the execution of an activity entitled "Field Exit", in partnership with students of the seventh year of the School "Renato Filgueiras", for the acquisition of photographic material in stretches of the "Estribeira" stream. In turn, the work developed in the third and last stage sought to accompany the process of processing slate from a local company in addition to visits to health centers of Papagaios.

Keywords: Mining, Slate, Beneficiation, Papagaios, Stream of the "Estribeira".

\section{INTRODUÇAO}

Fala-se desde a década de 70, no Brasil, sobre desenvolvimento sustentável. Percebem-se tentativas de conciliar avanços econômicos e a preservação da natureza; gerar riquezas e distribuí-las de forma justa, melhorando a qualidade das relações entre homem e meio ambiente.

Segundo Redclift (1996, p.5) a relação entre o homem e o ambiente pode ser controversa, visto que o homem ao ocupar um espaço, pode alterar o equilíbrio natural. A alteração ambiental geralmente é causada pela dispersão dos resíduos oriundos de processos domésticos ou industriais. Estes rejeitos podem modificar propriedades do solo, da água, do ar, sendo necessário um planejamento para minimizar as alterações ambientais. Desse modo,

\footnotetext{
Cada vez mais a questão ambiental está se tornando matéria obrigatória nas agendas de empresas. A globalização dos negócios, a internacionalização dos padrões de qualidade ambiental descritos na série ISO 14000, a conscientização crescente dos atuais consumidores e a disseminação da educação ambiental nas escolas permitem antever que a exigência futura que farão os futuros consumidores em relação à preservação do meio disto, as organizações deverão, de maneira acentuada, incorporar a variável ambiental na prospecção de seus cenários e na tomada de decisão, além de manter uma postura responsável de respeito à questão ambiental (DONAIRE, 1999, p 49).
}

Por desenvolvimento sustentável entende-se que é o processo de atendimento das necessidades humanas sem comprometimento das gerações futuras. Na prática, é percebido, nas comunidades a partir do momento em que esta valoriza o espaço na qual está inserida. (ANDRADE, 2002, p.43).

O papel da educação ambiental, numa abordagem sustentável, é, além de favorecer o diálogo, ou seja, além da busca racional pela solução do problema, busca também, despertar e sensibilizar as gerações em relação ao ambiente, de maneira coletiva e que envolva a promoção da sustentabilidade. Nessa perspectiva, a meta desta educação é desenvolver uma população mundial preocupada com o meio ambiente, para atuar individual e coletivamente na busca de soluções atuais, bem como viabilizar 
a prevenção de novos problemas, tornando os indivíduos mais sensíveis em relação ao meio ambiente proporcionando conhecimentos sobre o meio e de suas atividades. (BARBIERI, 2006)

A evolução da tecnologia, das necessidades sociais, o aumento populacional são fatores que podem aumentar o consumo de recursos naturais e consequentemente ampliar a quantidade de alterações no meio ambiente, caracterizando os impactos ambientais.

De acordo com a resolução do Conselho Nacional do Meio Ambiente, (CONAMA 001/86), artigo $1^{\circ}$, impacto ambiental é toda alteração das propriedades físicas, químicas e biológicas do meio ambiente, causadas por qualquer forma de matéria ou energia resultante das atividades humanas, que, diretamente ou indiretamente, afetem a segurança e o bem estar da população, bem como as atividades sociais e econômicas, a biota e as condições estéticas e sanitárias

As atividades de extração mineral e beneficiamento são importantes economicamente, porém, causam impactos ambientais no ar, solo e águas. Durante o beneficiamento de ardósia, por exemplo, no município mineiro de Papagaios, são produzidas 4,5 milhões de toneladas de rejeitos, que são depositadas de forma inadequada no ambiente. Desta forma, o solo, água e ar, recebem resíduos, o que acarreta no rompimento do equilíbrio do meio. (AMAR-MG, 2017).

Como área de estudo a cidade Papagaios, inserida num contexto extrativista e beneficiador de ardósia, foi caracterizada nos seguintes aspectos: história, geografia, economia, além da caracterização física (geomorfologia, geologia, solos, recursos hídricos, cobertura vegetal e legislação).

O objetivo do trabalho foi identificar os impactos ambientais causados pelo beneficiamento da ardósia no município de Papagaios. Buscou-se também caracterizar o processo de legislação ambiental, o passivo ambiental local e propor alternativas de reutilização de resíduos gerados.

\section{REVISÃO LITERATURA}

\subsection{CARACTERIZAÇÃO HISTÓRICA E ECONÔMICA}

\subsubsection{A história de Papagaio}

Papagaios (MG), está localizada a $150 \mathrm{~km}$ da capital mineira, conforme figuras: 1 e 2, e possui

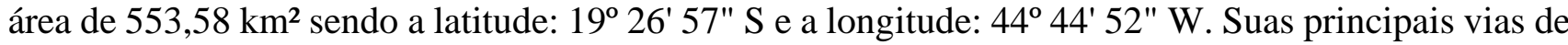
acesso à capital são: BR-262, BR-431, BR-381, MG-060. (IBGE, 2016) 


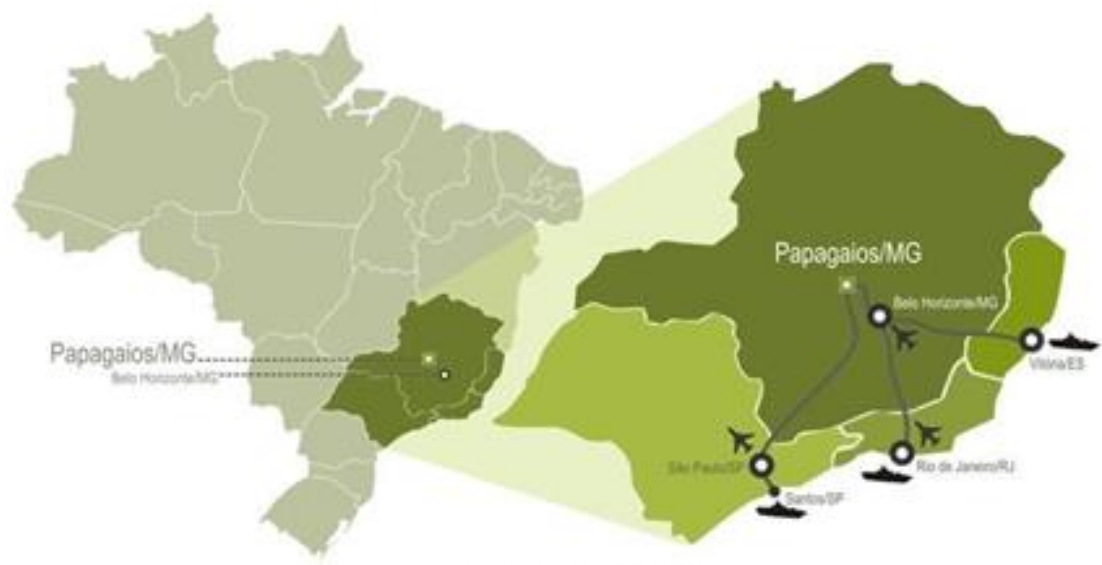

Fonte: Google Imagens

Figura 2 - Localização Real de Papagaios

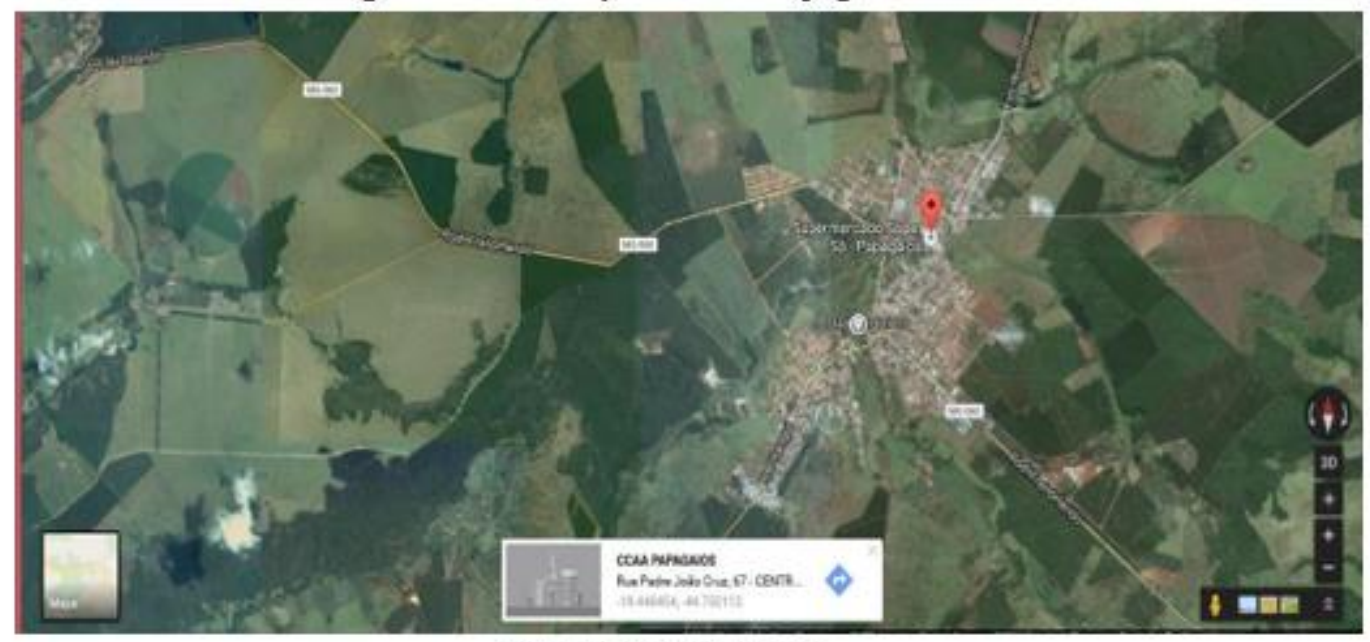

Fonte: Google Imagens.

Segundo registro da Prefeitura Municipal, em 1780, o espaço ocupado pela atual cidade pertencia ao casal Manuel e Catarina Gonçalves Fraga, sendo denominada, neste período, por "Fazenda de Morrinhos". O proprietário, Sr. João Fraga, pai de Dona Catarina, era um grande caçador e possuía uma sesmaria de terra sem documentação, que conforme relatos locais fora doada por D. Pedro I devido à grande amizade, que inclusive, de acordo com a tradição histórica local, lá se hospedava quando vinha do Rio de Janeiro de liteira - gastando por volta de treze dias de viagem. A fazenda recebeu o nome de "Morrinhos" porque era rodeada por cinco pequenos morros: Malhadinha, Morro da Anta, Morro da Boa Vista, Morro do Urubu e Morro do Chapéu. Não se sabe precisamente quando houve a troca de nomes de Morrinhos para Papagaios. Sabe-se, no entanto, que, até aproximadamente 1780, a localidade ainda era de propriedade do casal Gonçalves Fraga, pois há uma carta conservada pelo Coronel Américo Cordeiro onde D. Joaquina do Pompéu dirigia-se à D. Catarina para comprar "uma junta de bois". 
Após a morte do casal, a fazenda ficou sem donos. Presume-se que os dois filhos não deixaram descendentes, uma vez que ninguém apareceu para requisitar a herança. Dentro de poucos anos, a fazenda transformou-se em um povoado. Outra versão dos fatos é que o casal, Manoel e Catarina Gonçalves Fraga, proprietários da fazenda Morrinhos, faleceram sem deixar herdeiros, já que seus dois únicos filhos haviam desaparecido. Uma vez abandonada, a propriedade deu origem ao povoado que denominaram de Papagaios. A origem do nome tem duas versões: a primeira diz da existência de um papagaio falador na região; a segunda, de uma várzea conhecida como Várzea do Papagaio. (AMARMG, 2017).

O certo é que o distrito surgiu em 1911, pertencendo à Maravilhas, cidade situada a $11 \mathrm{~km}$ de Papagaios. Em 1953, tornou-se município, e, atualmente, pertence à comarca de Pitangui. Quanto a grafia do nome da cidade, admite-se as formas: Papagaio e Papagaios, sendo a última mais utilizada, embora oficialmente a denominação correta seja Papagaio.

$\mathrm{Na}$ tentativa de caracterizar geograficamente o município, a seguir, são apresentadas algumas informações, através da figura 3, gráficos (1 ao 4) e da tabela 1.

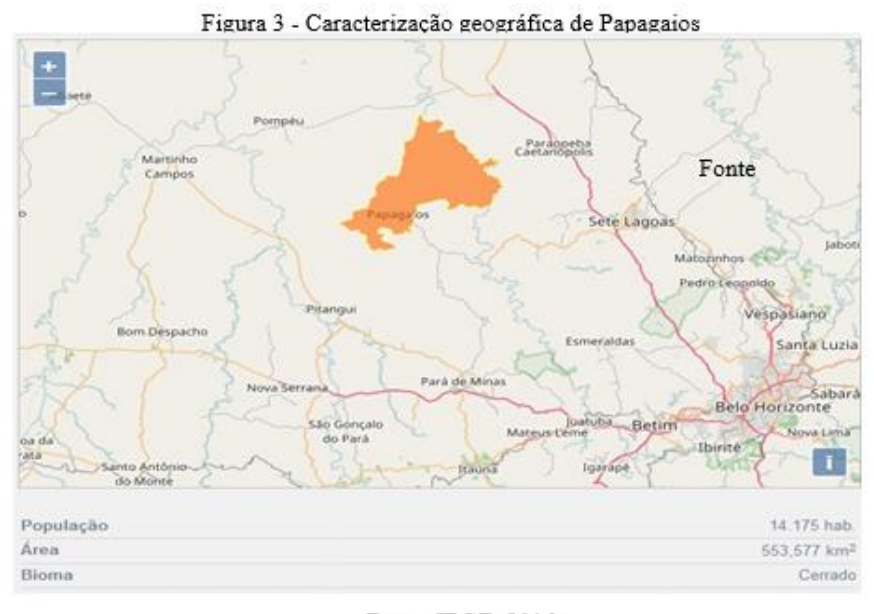

Fonte: IBGE, 2016

Tabela 1 - População de Papagaios

\begin{tabular}{|c|c|}
\hline ANO & $\begin{array}{c}\text { POPULAÇÃO } \\
\text { (habitantes) }\end{array}$ \\
\hline 1970 & 6.304 \\
\hline 1980 & 6.625 \\
\hline 1991 & 10.119 \\
\hline 2001 & 12.472 \\
\hline 2004 & 14.410 \\
\hline 2009 & 15.384 \\
\hline
\end{tabular}


Gráfico 1 - Caracterização população de Papagaios 2013
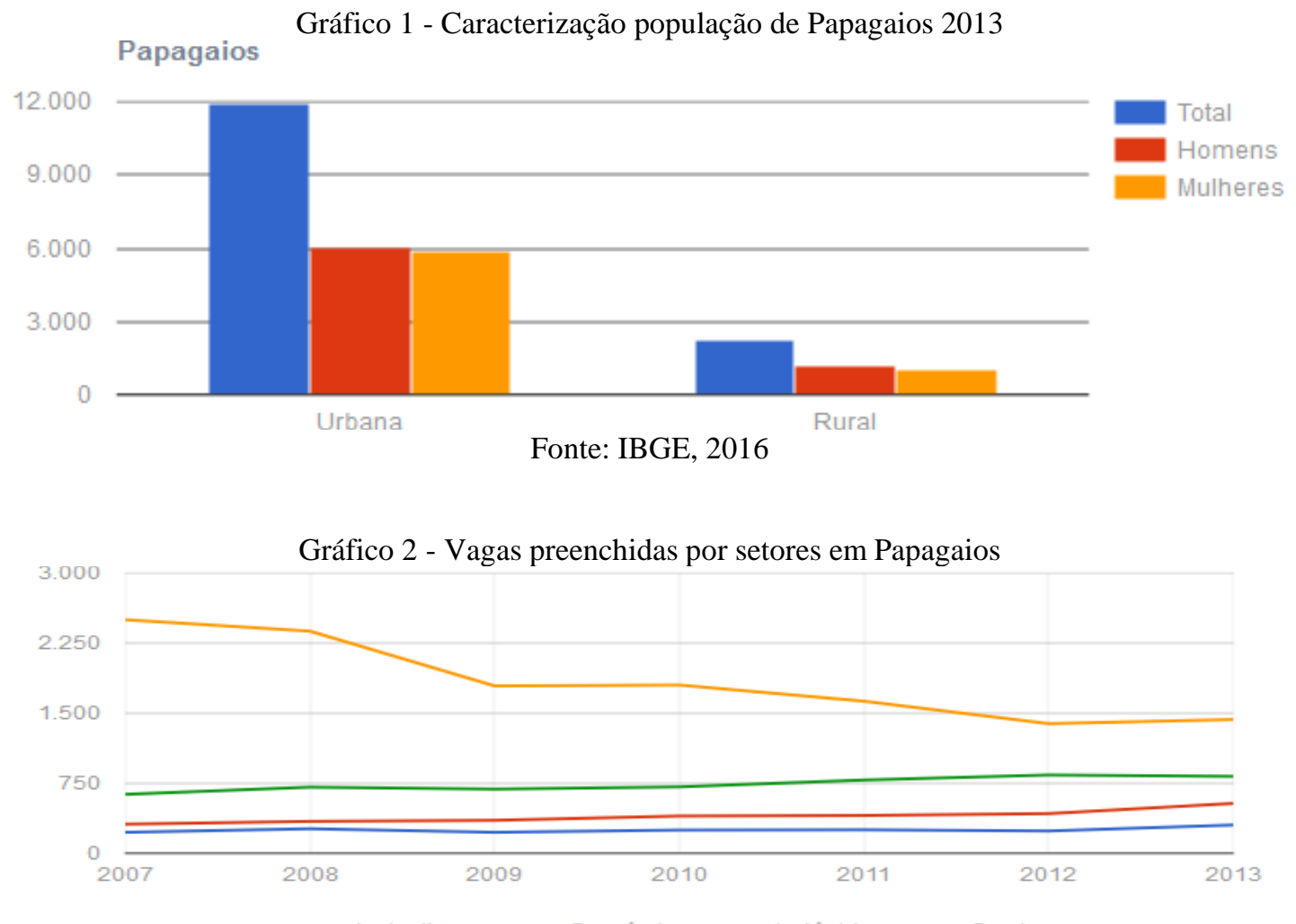

Fonte: IBGE, 2016

Gráfico 3 - PIB municipal, estadual e federal 2013

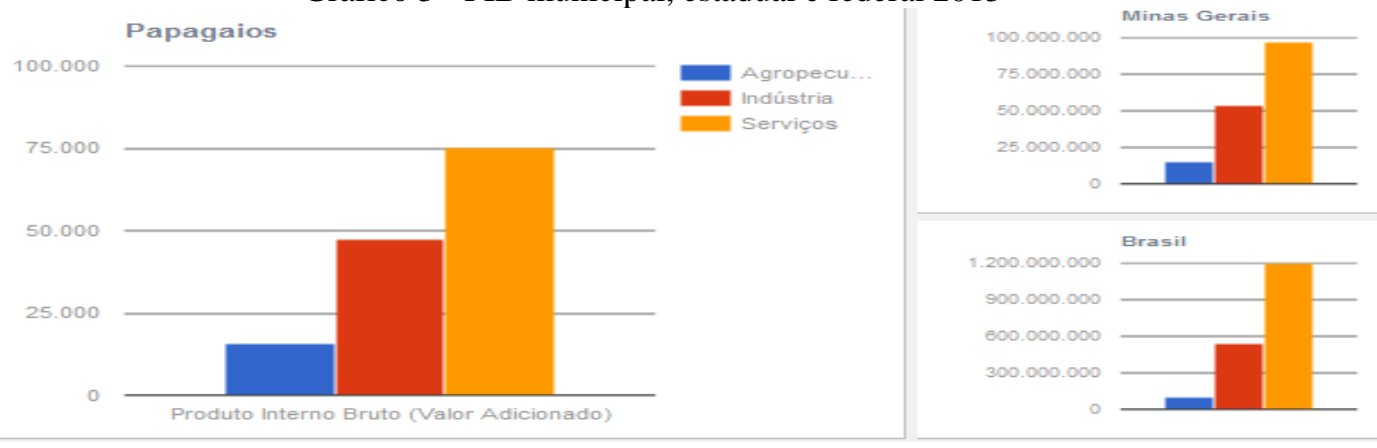

Fonte: IBGE, 2016 


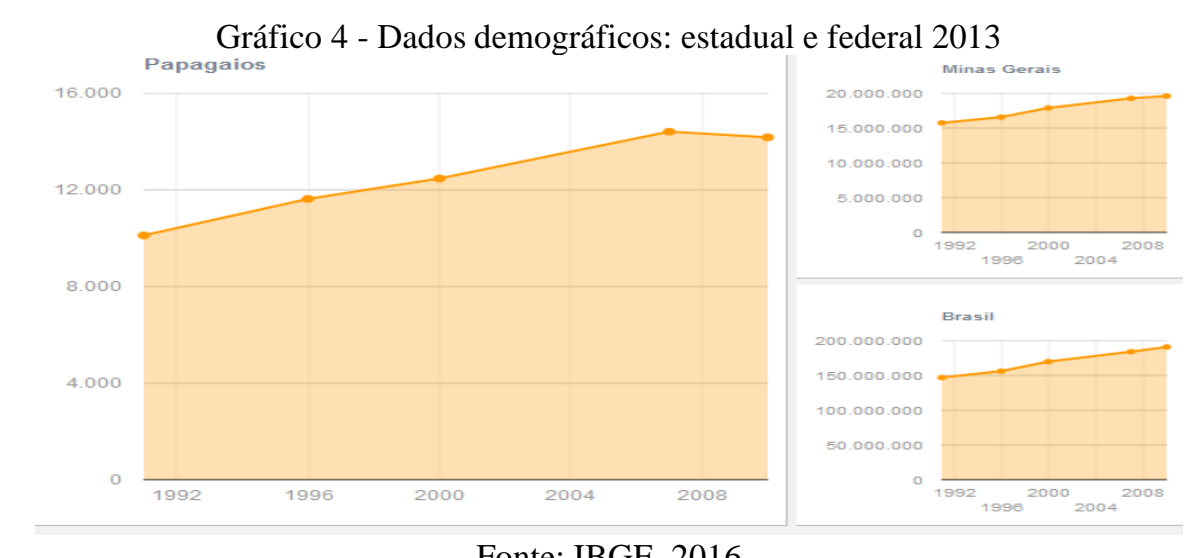

Fonte: IBGE, 2016

Gráfico 4 - Dados demográficos: estadual e federal 2013

\subsubsection{A ardósia}

Nos anos iniciais de 2000, Papagaios foi considerada capital mundial da ardósia. Conforme figura 4, vê-se diversas marcações, em vermelho, que delimitam os empreendimentos beneficiadores de ardósia

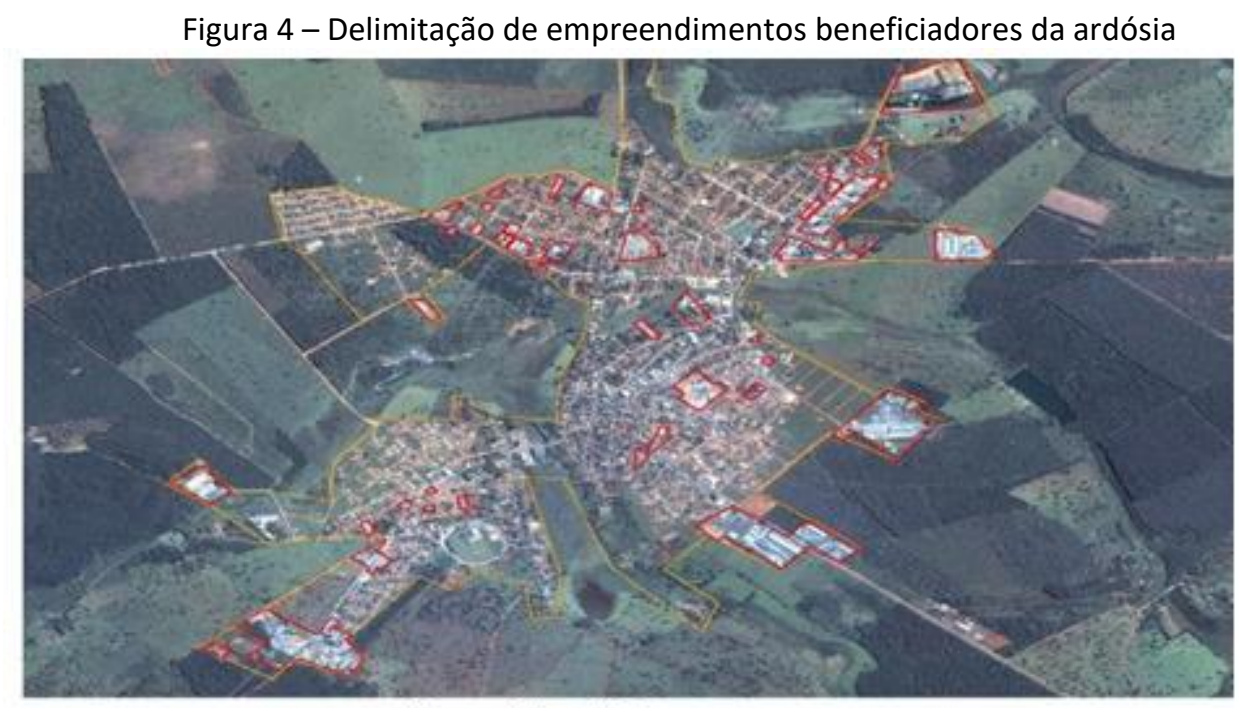

Fonte: Google Imagens

Ardósias são rochas finas com pouca metamorfose, com clivagem ardosiana e abertura em chapas muito finas. A orientação é resultante da pressão mecânica, ou da recristalização mineralógica além da rotação dos cristais. (CHIODI FILHO, 2004)

As propriedades físicas destas rochas como: clivagem preferencial, dureza média, baixa porosidade, alta resistência mecânica, minerais constituintes resistentes ao intemperismo etc. Tais características permitem a ampla utilização como revestimento como pisos e telhados inclusive em países que aplicam rígidos padrões técnicos e ambientais na lavra e beneficiamento (BARBOSA, 1974, p 248). 
As composições químicas e mineralógicas das ardósias e do resíduo denominado "lama de ardósia", e um ensaio realizado podem ser observados nas tabelas: 2, 3, 4

Tabela 2 - Composição mineralógica das ardósias.

\begin{tabular}{|c|c|}
\hline AMOSTRA & MINERAIS IDENTIFICADOS \\
\hline Lama de ardósia & Muscovita, Quartzo, Feldspato, Clorita \\
\hline Ardósia Cinza & Muscovita, Quartzo, Feldspato, Clorita \\
\hline Ardósia Verde & Muscovita, Quartzo, Feldspato, Clorita \\
\hline Ardósia Grafite & Muscovita, Quartzo, Feldspato, Clorita e Montmorilonita \\
\hline Ardósia Roxa & Muscovita, Quartzo, Feldspato, Clorita \\
\hline \hline
\end{tabular}

Fonte: Anais do $45^{\circ}$ Congresso Brasileiro de Cerâmicas, 2001

Tabela 3 - Composição química das ardósias

\begin{tabular}{|c|c|c|c|c|c|}
\hline \multirow{2}{*}{ óxido } & \multicolumn{5}{|c|}{ Composição química (\%) } \\
\cline { 2 - 6 } & roxa & verde & Cinza & grafite & lama \\
\hline Perda ao fogo & 3,66 & 3,60 & 3,84 & 4,22 & 4,68 \\
\hline $\mathrm{SiO} 2$ & 60,00 & 58,76 & 60,10 & 58,61 & 56,65 \\
\hline $\mathrm{Al} 2 \mathrm{O} 3$ & 19,48 & 22,69 & 20,11 & 19,92 & 22,49 \\
\hline $\mathrm{Fe} 2 \mathrm{O} 3$ & 6,22 & 5,23 & 5,63 & 6,86 & 5,93 \\
\hline $\mathrm{TiO} 2$ & 0,67 & 0,68 & 0,69 & 0,69 & 0,70 \\
\hline $\mathrm{CaO}$ & 0,65 & 0,67 & 1,09 & 0,77 & 1,11 \\
\hline $\mathrm{MgO}$ & 2,60 & 2,54 & 2,53 & 2,89 & 2,82 \\
\hline $\mathrm{Na} 2 \mathrm{O}$ & 1,78 & 1,60 & 2,07 & 1,95 & 1,96 \\
\hline $\mathrm{K} 2 \mathrm{O}$ & 4,68 & 4,08 & 3,61 & 3,84 & 3,55 \\
\hline
\end{tabular}

Fonte: Anais do $45^{\circ}$ Congresso Brasileiro de Cerâmicas, 2001

Tabela 4 - Composição física das ardósias

\begin{tabular}{|c|c|c|c|c|c|c|}
\hline Mistura & $\begin{array}{c}\text { Retração } \\
\text { linear } \\
(\%)\end{array}$ & $\begin{array}{c}\text { MRF* } \\
(\mathrm{MPa})\end{array}$ & $\begin{array}{c}\text { Mea** } \\
\left(\mathrm{g} / \mathrm{cm}^{3}\right)\end{array}$ & $\begin{array}{c}\text { Porosidade } \\
\text { aparente } \\
(\%)\end{array}$ & $\begin{array}{c}\text { Absorção } \\
\text { d'água }^{*}(\%)\end{array}$ & $\begin{array}{c}\text { Perda ao } \\
\text { Fogo } \\
(\%)\end{array}$ \\
\hline $\mathrm{A}$ & 0,4 & 6,78 & 1,9 & 31,3 & 16,8 & 3,5 \\
\hline $\mathrm{B}$ & 0,1 & 7,75 & 1,9 & 31,5 & 17,0 & 3,5 \\
\hline $\mathrm{C}$ & 0,3 & 6,54 & 1,9 & 30,4 & 16,1 & 3,5 \\
\hline $\mathrm{D}$ & 0,1 & 8,13 & 1,9 & 29,8 & 15,8 & 3,5 \\
\hline
\end{tabular}

Fonte: Anais do $45^{\circ}$ Congresso Brasileiro de Cerâmicas, 2001

As ardósias constituem um recurso mineral mundialmente conhecido, de ampla utilização para revestimentos, sendo o estado mineiro o segundo maior polo minerador brasileiro de rochas em quantidade, primeiro em diversidade de materiais extraídos e segundo em volume físico e valor de exportações no setor. Estima-se a existência de 200 frentes ativas de lavra em Minas Gerais, com uma produção de 2 milhões de toneladas por ano. Essa produção distribui-se por mais de 50 municípios, incluindo a extração de granitos (700 mil toneladas/ano), ardósias (580 mil toneladas/ano) e quartzitos (500 mil toneladas/ano); além de pedra sabão, pedra talco, pedra Lagoa Santa e pedra Preta Mariana, que compõem quase 180 variedades comerciais colocadas nos mercados interno e externo. Cerca de duas mil empresas atuam nos segmentos de 
lavra, beneficiamento e marmoraria, no estado representando investimentos privados da ordem de US\$ 500 milhões. As transações comerciais do setor no estado mineiro devem movimentar, aproximadamente, 600 milhões de dólares por ano. (CHIODI FILHO, 2004, p 122)

Destacaram-se, nesse ramo, aproximadamente 550 empresas, sendo 70 na área extrativa. Em 2005, a cidade contava com 25 pedreiras e cerca de 200 indústrias de beneficiamento, que geravam cinco mil empregos diretos e mais cinco mil indiretos, sendo o município, neste período, responsável por metade da produção nacional de ardósia. As principaisvariedades de cores das ardósias produzidas pelas empresas locais, podem ser vistas na figura 5, sendo as cores: cinza, verde, vinho, preta além da ferrugem. Quanto a forma de utilização, a figura 6, mostra possíveis formas de uso das ardósias. (AMAR-MG, 2017).

Figura 5 - Cores de ardósia produzidas na região

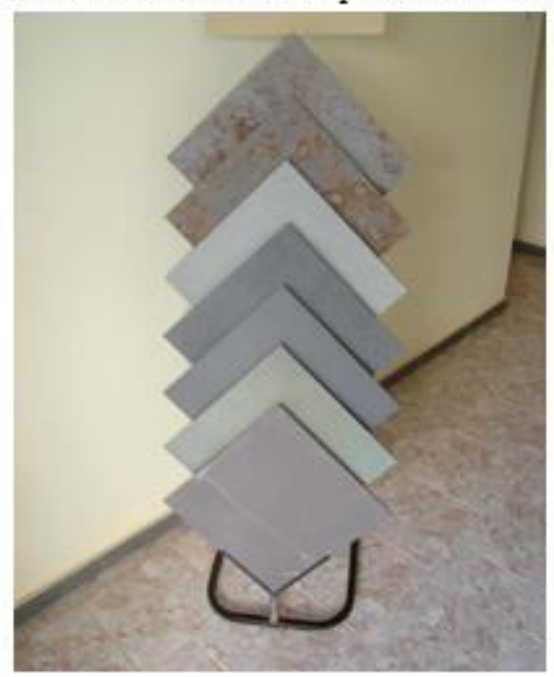

Figura 6 - Revestimentos de interiores e exteriores
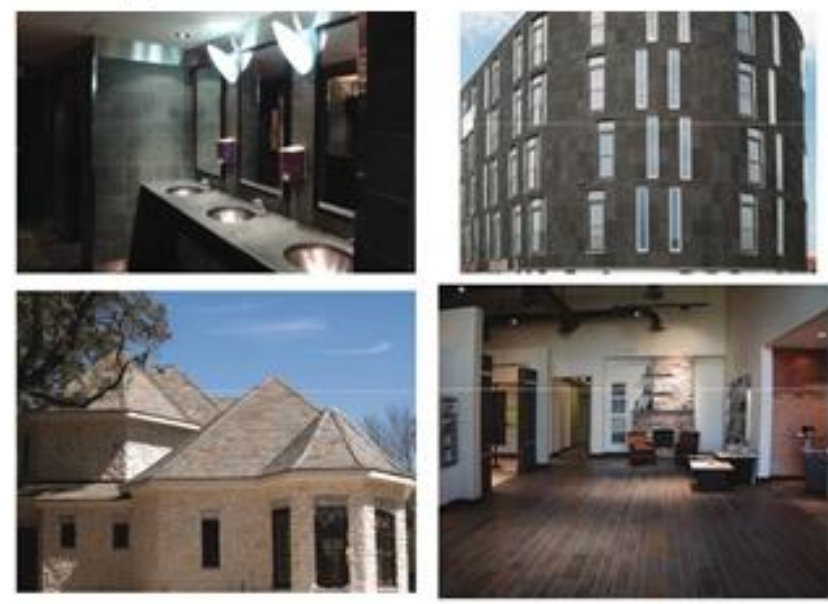

Fonte: FEAM, 2000 
Entretanto, as atividades de extração e beneficiamento em Papagaios geram resíduos industriais, nas formas sólidas e líquidas. Localmente, por ano, são gerados volumes expressivos de rejeitos na forma de aparas, cujo descarte é realizado em "bota-fora" de maneira ilegal, próximos às lavras ou unidades de beneficiamento, denominadas "serrarias de ardósia, conforme a figura 7. (AMAR-2017).

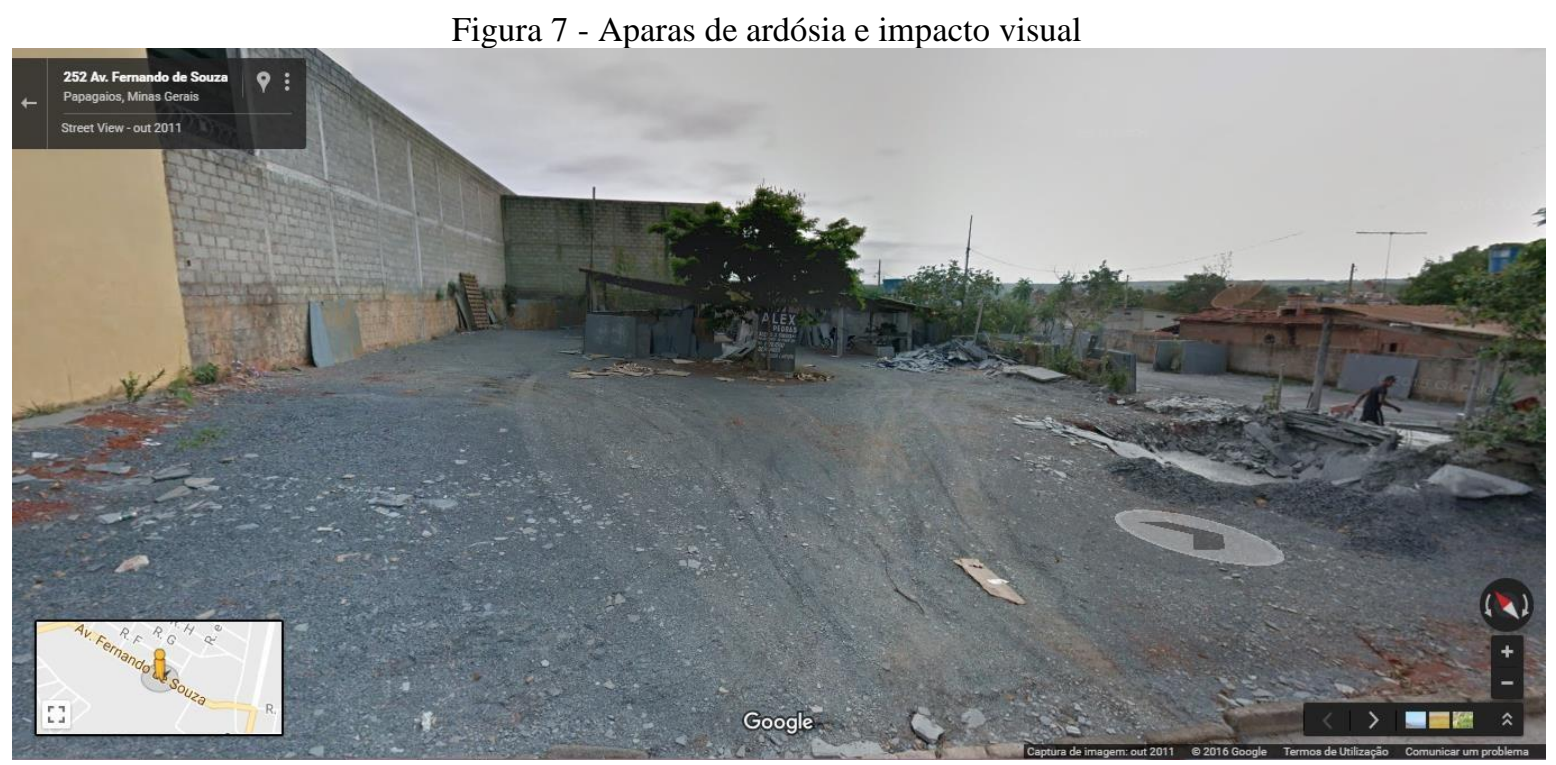

Fonte: Google Imagens

Além do impacto visual, há outros impactos ambientais no município, como a contaminação da atmosfera, que ocorre pela emissão de gases provenientes da queima de combustíveis utilizados nos equipamentos e maquinários tais como escavadeira, pá carregadeira, caminhões, constituindo-se de monóxido de carbono, óxidos de enxofre e nitrogênio, hidrocarbonetos. Há, também, a geração de poeira através do movimento dos caminhões de transporte de rejeito até as áreas de "pilha de estéril/rejeito" e, ainda, a movimentação atípica de veículos, sobretudo de carga, ligados ao transporte do produto conforme vista em atividade de campo.

Para minimizar os efeitos gerados pela emissão de poeiras, no período das secas, é feita a aspersão d'água nas estradas internas a cava e de acessos. A geração de ruídos ocorre durante os trabalhos de lavra e beneficiamento, originados através da operação dos equipamentos, tais como: escavadeiras, pás carregadeiras, serras de disco, bombas d'água e caminhões. Algumas operações se realizam em espaços abertos e em área totalmente rural, com isso, seus efeitos são minimizados. (AMAR-2017)

O carreamento de sólidos também pode ocorrer na pilha de estéril/rejeito e na área da mina. Segue, abaixo, duas imagens (figura 8 e figura 9) de uma mesma mina de ardósia em 
diferentes épocas do ano, mostrando rejeitos e aparas gerados na extração. Ademais efluente líquido, produzido nas serrarias de ardósia é mostrado na figura 10, obtida na atividade "Trabalho de Campo".

Figura 8 - Mina de ardósia empresa da região em 2017

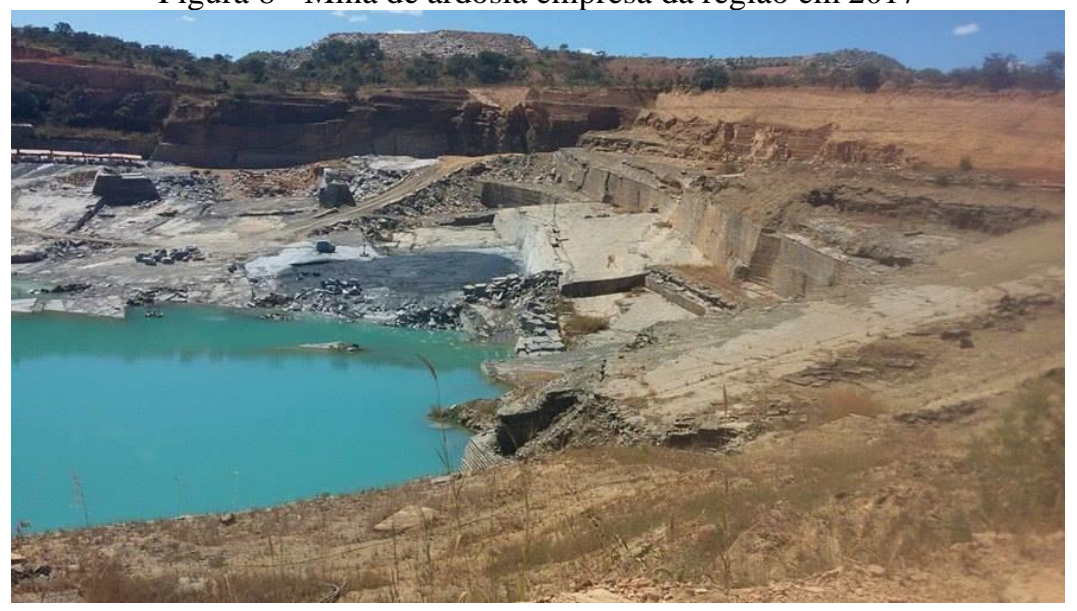

Figura 9 - Mina de ardósia empresa da região em 2017

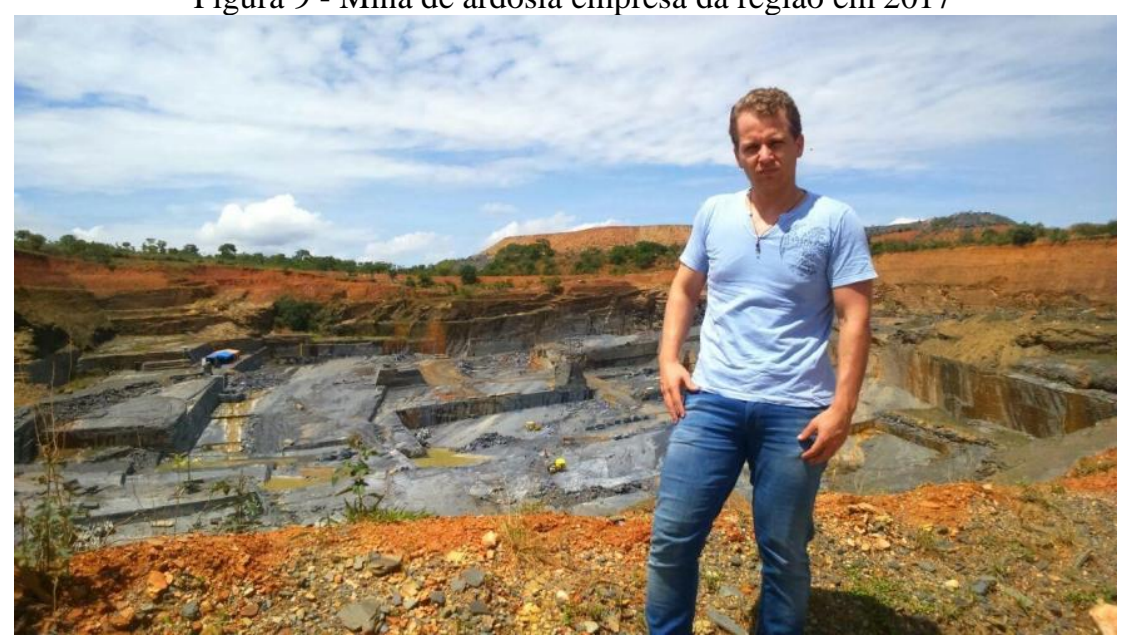


Figura 10 - Efluente lançado no córrego da Estribeira

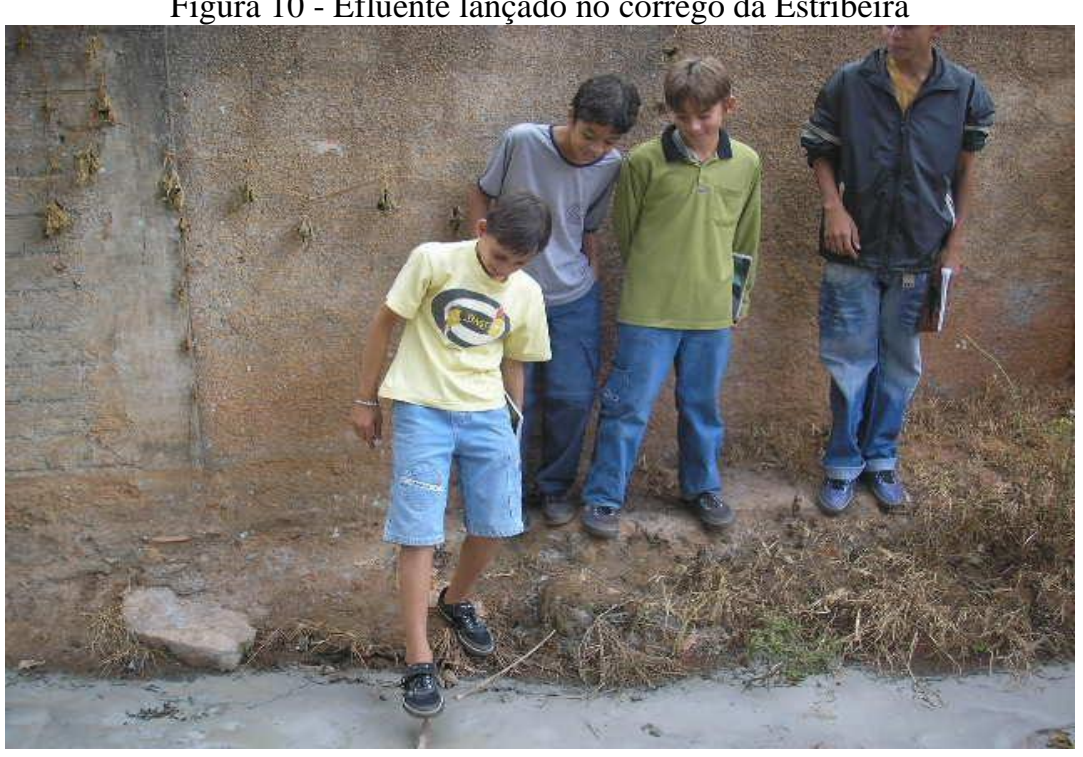

\subsection{IMPACTOS AMBIENTAIS}

\subsubsection{Legislação ambiental e a mineração}

A legislação brasileira oferece normas e leis relativas à conservação e gerenciamento dos recursos naturais. Estabelece responsabilidades civis, penais e administrativas para os responsáveis por danos ao meio ambiente.

Houve um desenvolvimento significativo da legislação ambiental brasileira, nos últimos anos. Na história desta evolução cita-se como importantes marcos a Constituição Federalde 1988,

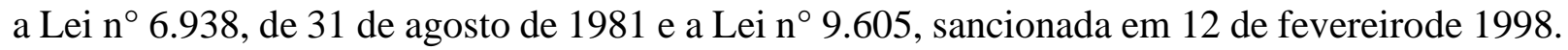
A Constituição Federal de 1988 diz que todos têm direito a um ambiente ecologicamente equilibrado, cabendo ao Poder Público e à coletividade a obrigação de defendê- lo e preservá-lo; determina, também, que aquele que explorar recursos minerais fica obrigado a recuperar o meio ambiente degradado e prevê sanções administrativas e penais para as condutase atividades consideradas lesivas ao meio ambiente, independentemente da obrigação de recuperação do dano causado. (SALES,1999)

A Lei $\mathrm{n}^{\circ}$ 6.938/81 criou instrumentos de política ambiental, dentre eles, merecem destaque: o estabelecimento de padrões de qualidade ambiental, o zoneamento ambiental, a avaliação de impactos ambientais e o licenciamento e a revisão de atividades efetiva e potencialmente poluidoras.

A Lei n 9.605/98 é conhecida como a "Lei de Crimes Ambientais" e define os crimes contra a natureza, estabelecendo as penas para os mesmos. Tal lei pode ser considerada instrumento de defesa ambiental no momento, pois, antes dela, as infrações administrativas e 
penais relativas ao meio ambiente se baseavam em uma legislação esparsa e, muitas vezes, tecnicamente deficiente, o que favorecia, em grande medida, os infratores (SEMAD, 2017)

Alguns aspectos da Lei 9.605/98

1)a definição da responsabilidade da pessoa jurídica, inclusive criminalmente, bemcomo da pessoa física, autora ou co-autora da infração;

2)liquidação forçada da empresa no caso de ser criada e/ou utilizada para permitir,facilitar ou ocultar crime definido em lei;

3)a extinção da punição com a apresentação de laudo que comprove a recuperaçãodo dano ambiental.

O tratamento dado ao meio ambiente, na atual Constituição, e as consequentes modificações sofridas pela legislação ambiental ordinária após sua promulgação, colocaram o Brasil na linha de frente, junto aos países mais adiantados do mundo, em matéria de direito ambiental (SEMAD, 2016).

Os empreendimentos, visando regularização ambiental, são classificados de acordo com a Deliberação Normativa Copam 74/04. Considera-se o porte do empreendimento e o potencial poluidor, que em conjunto, definem a classe do empreendimento. A tabela 5, mostra as classes possíveis dos empreendimentos.

Tabela 5 - Classificação de empreendimentos

\begin{tabular}{|l|}
\hline Classe 1 - pequeno porte e pequeno ou médio potencial poluidor \\
\hline Classe 2 - médio porte e pequeno potencial poluidor \\
\hline Classe 3 - pequeno porte e grande potencial poluidor ou médio porte e médio potencial poluidor \\
\hline Classe 4 - grande porte e pequeno potencial poluidor \\
\hline Classe 5 - grande porte e médio potencial poluidor ou médio porte e grande potencial poluidor \\
\hline Classe 6 - grande porte e grande potencial poluidor \\
\hline
\end{tabular}

Fonte: SIAM,2016

Em Minas Gerais, as atribuições do licenciamento ambiental e da Autorização Ambiental de Funcionamento (AAF) são exercidas pelo Conselho Estadual de Política Ambiental (Copam), das Unidades Regionais Colegiadas (URCs), das Superintendências Regionais de Meio Ambiente e Desenvolvimento Sustentável (Suprams), conforme figura 11, que representa a Fundação Estadual de Meio Ambiente (Feam), o Instituto Mineiro de Gestão das Águas (Igam) e o Instituto Estadual de Florestas (IEF). (SIAM, 2016). 
Figura 11 - Superintendências Regionais de Meio Ambiente e Desenvolvimento Sustentável

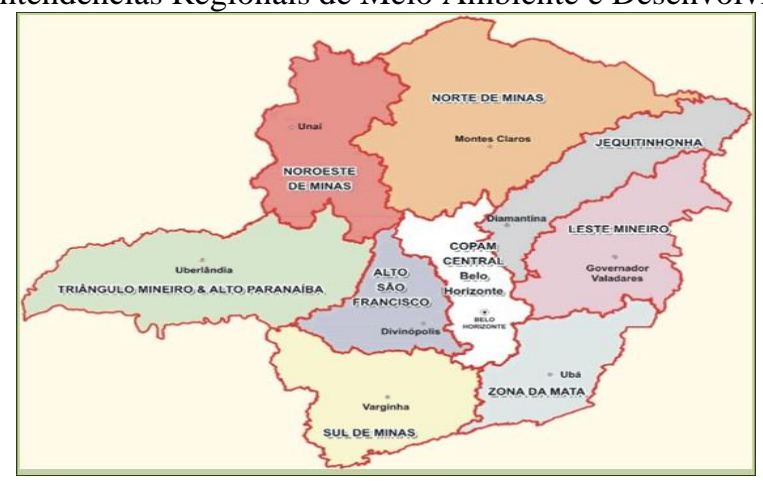

Fonte: SIAM, 2016

Para os empreendimentos classes 1 e 2, considerados de impacto ambiental não significativo, é obrigatória a obtenção da Autorização Ambiental de Funcionamento (AAF). Para as demais classes (3 a 6), o caminho para a regularização ambiental é o processo de

licenciamento, com o requerimento das licenças: Prévia (LP), de Instalação (LI) e de Operação (LO). A regularização ambiental de um empreendimento não termina, entretanto, com a obtenção da Licença de Operação (LO) ou da AAF. (SIAM, 2016)

$\mathrm{O}$ fato de ter obtido um ou outro desses diplomas legais, significa que o empreendimento atendeu a uma exigência legal, mas a manutenção da regularidade ambiental pressupõe o cumprimento permanente de diversas exigências legais e normativas, explícitas ou implícitas na licença ambiental ou na AAF. A seguir se encontra uma página da internet, com o número de um processo de uma empresa local, representado na figura 12. Faz-se necessário ressaltar que, de acordo com pesquisa no SIAM 2016 poucas empresas locais apresentam atividades licenciadas.

Figura 12 - Página da internet com licenciamento inacabado

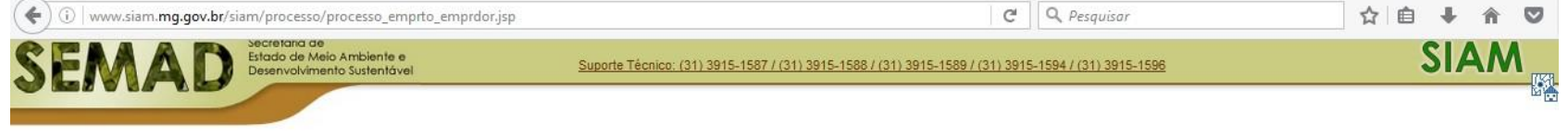

Siam - Sistema Integrado de Informação Ambiental
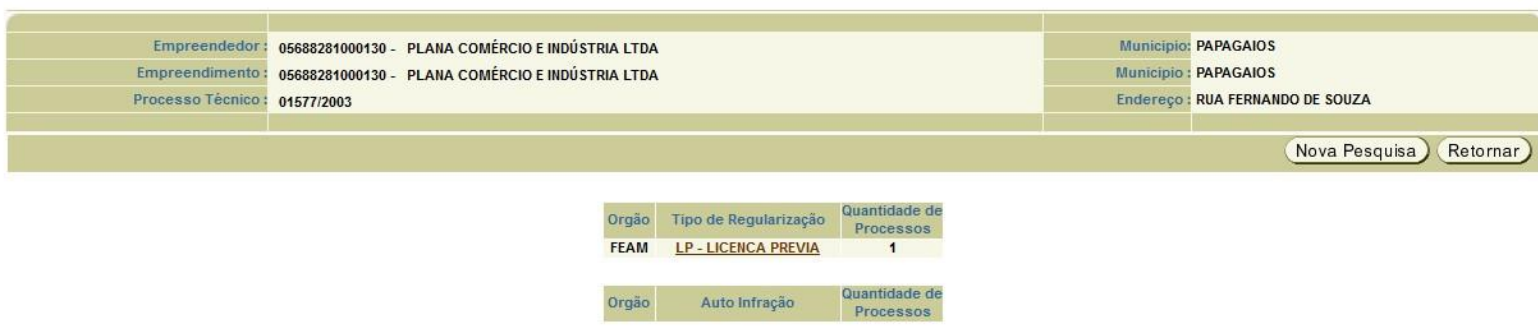

Fonte: SIAM, 2016 
Para os empreendimentos classes 1 e 2, considerados de impacto ambiental não significativo, é obrigatória a obtenção da Autorização Ambiental de Funcionamento (AAF). Paraas demais, classes (3 a 6), o caminho para a regularização ambiental é o processo de licenciamento, com o requerimento das Licenças Prévia (LP), de Instalação (LI) e de Operação (LO). A regularização ambiental de um empreendimento não termina, entretanto, com a obtenção da Licença de Operação (LO) ou da AAF. $\mathrm{O}$ fato de ter obtido um ou outro desses diplomas legais significa que o empreendimento atendeu a uma exigência legal, mas a manutenção da regularidade ambiental pressupõe o cumprimento permanente de diversas exigências legais e normativas, explícitas ou implícitas na licença ambiental ou na AAF. No casoespecífico da mineração, existe a Lei $n^{\circ} 14.940$, de 29 de dezembro de 2003 que institui o

Cadastro Técnico Estadual de Atividades Potencialmente Poluidoras ou Utilizadoras de RecursosAmbientais, de acordo com a tabela 6 (SEMAD, 2016).

Tabela 6 - Atividades potencialmente poluidoras e utilizadores de recursos ambientais

Código Categoria $\quad$ Descrição $\quad$ PP/GU

Pesquisa mineral com guia de utilização; lavra a céu aberto, inclusive de aluvião, com ou sem beneficiamento; lavra subterrânea com ou sem beneficiamento, lavra garimpeira, perfuração de poços e produção de petróleo e gás natural.

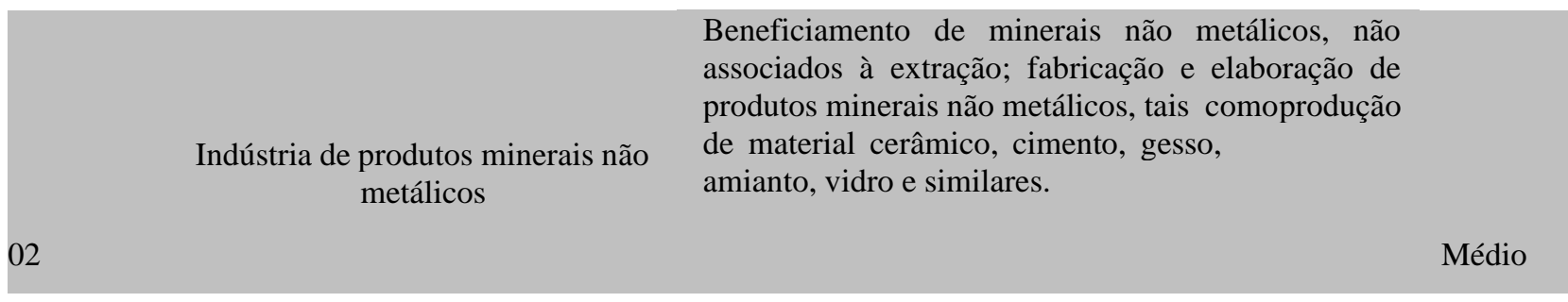

Fonte: FEAM, 2017

\subsection{CARACTERIZAÇÃO FÍSICA}

A seguir, será feito uma caracterização física, levando em consideração os aspectos geomorfológicos, geológicos, recursos hídricos, solos, e cobertura vegetal, tendo como referência a Província da Ardósia, representada na figura 13, cuja cidade de Papagaios está inserida. 


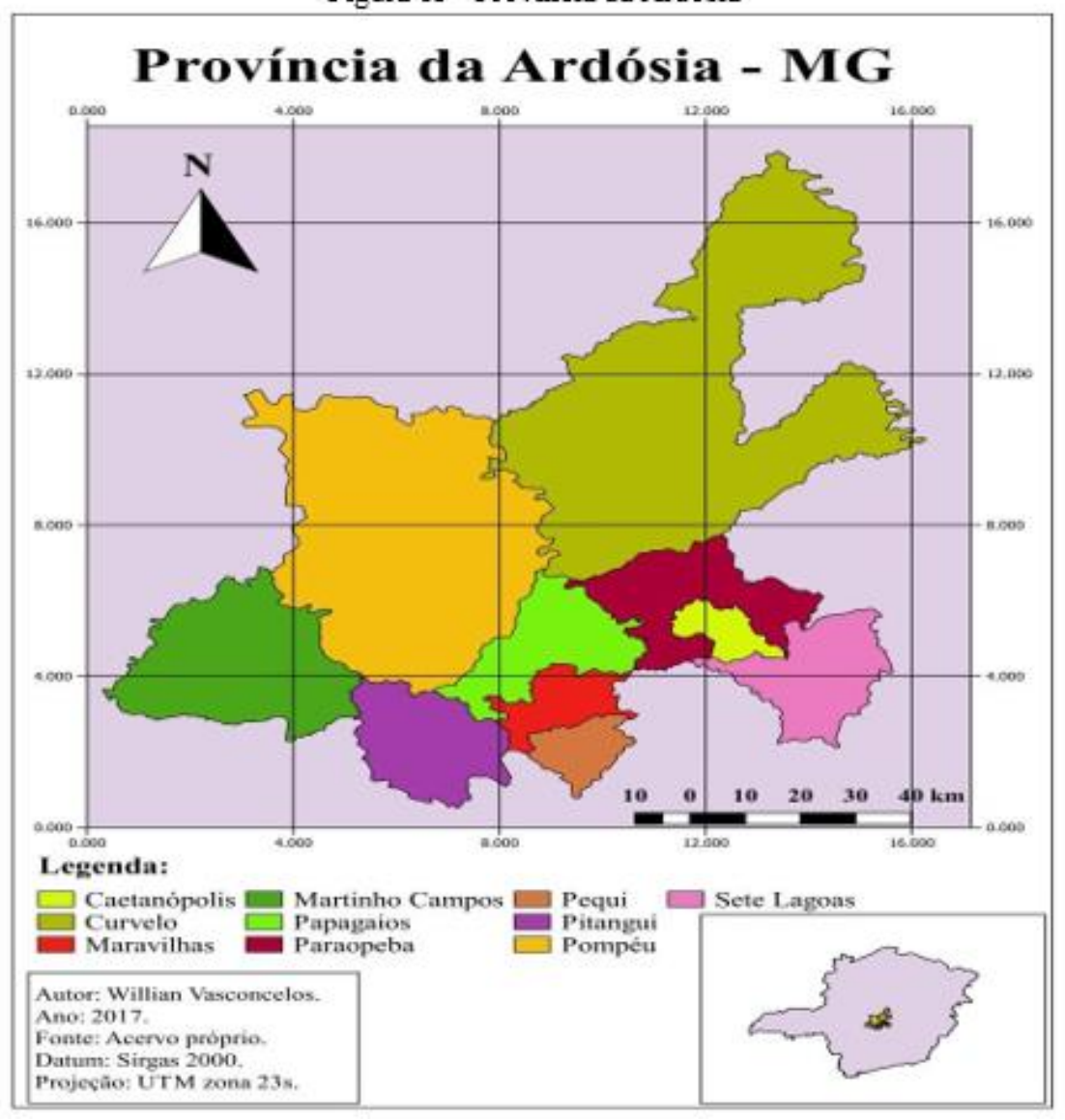

\subsubsection{Geomorfologia regional}

Papagaios está morfologicamente inserida na depressão Sanfranciscana, posicionada entre os chapadões sedimentares a oeste e os terrenos cristalinos mais antigos a leste. No interior da depressão Sanfranciscana encontra-se a superfície de aplainamento pleistocênica. Sua evolução se processou a partir do entalhamento dos vales principais, condicionados por fraturamentos pré-Cambrianos, refletidos pela orientação geral de seus grandes rios (sudestenoroeste) Paraopeba e Pará. O desenvolvimento lateral da depressão decorreu da atuação de processos de sedimentação, que a rebaixaram e aplainaram de modo homogêneo. Localmente, a área do estudo, compõe uma pequena elevação com cota máxima de 700m, de forma arredondada. A leste deste, situa-se a Serra do Ibiruçu, com altitudes máximas de $1.065 \mathrm{~m}$, que corresponde às maiores elevações dentro da Província de Ardósia. (EIA, Estudo de Impacto Ambiental Lavrar Mineração Ltda, 2000).

A oeste da depressão Sanfranciscana, há lagoas refletindo um terreno calcário, com desenvolvimento de dolinas, em altitudes próximas de $700 \mathrm{~m}$. No sentido norte, a topografia fica mais arrasada, com cotas máximas passando para a faixa dos 650-680 m, culminando no rio Paraopeba. A rede de drenagem possui uma antiguidade expressiva, conforme pode-se notar nas 
numerosas gargantas de superposição, através das quais os cursos d'água cortam as estruturas regionais. A superposição da drenagem se processou a partir de uma superfície de aplainamento de âmbito continental, a Superfície Sul-Americana do Terciário Superior. Esse caimento constitui o mais antigo condicionamento morfológico da drenagem atual. O rio Paraopeba possui declividade média da ordem de 3 a 5,5\%. Seu vale é basicamente em U, com grandes áreas com planícies fluviais. Apesar de cortar terrenos calcários, com desenvolvimento de dolinas, não se constata a presença de sumidouros e de cavernas na região. Os processos erosivos que se desenvolvem na região não se mostram muito ativos, são processos naturais, incrementados pela interferência antrópica, especialmente o desmatamento. As práticas agrícolas, muitas delas inadequadas, deram origem a formas de erosão acelerada nos locais próximos da lavra experimental, onde foram anotados processos erosivos, com aspecto de voçoroca e de outras formas de ravinamento. (CHIODI FILHO, 2003).

\subsubsection{Geologia}

A Província de Ardósia é originária de regiões onde as rochas mantiveram-se horizontais. Dentro da geologia regional, destaca-se o grupo "Bambuí" que é datado do Proterozóico Superior (600-500 Ma), tendo desenvolvimento associado ao Ciclo Brasiliano do Proterozóico Superior Cambriano. A principal sequência correlacionada ao Bambuí, no âmbito da Província, refere-se ao Grupo Paraopeba. O Membro Superior tem mais de $140 \mathrm{~m}$ de espessura e é constituído por siltitos argilosos e folhelhos sílticos de coloração acinzentada e esverdeada; as rochas são fortemente clivadas e formam leitos e espessura variável, fornecendoas ardósias comerciais cinzas, verdes, roxas e ferrugem. (PARENTI COUTO, 1980)

O Membro Médio tem no máximo $50 \mathrm{~m}$ de espessura e possui folhetos escuros. O Membro Inferior não aflora nas porções centrais e norte da Província, mas está bem representado na sua porção sul, onde, tanto ocorre capeando os calcários da Formação Sete Lagoas, quanto assentado diretamente sobre o Complexo Basal (xistos, gnaisses, migmatitos e granitos, de idade arqueana); ele é formado por siltitos argilosos, metasiltitos e ritmitos, cinza-escuros a negros e com algum carbonato, tendo espessura superior a 90 m e encerrando as ardósias negras e grafite. (EIA, Estudo de Impacto Ambiental Lavrar Mineração Ltda, 2000).

\subsubsection{Solos}

Os solos têm suas características condicionadas principalmente aos tipos litológicos sobre os quais atuaram os processos pedogenéticos, além de outros fatores de formação como tempo, 
relevo clima e organismos. Na região em estudo, predominam os latossolos vermelho amarelo distrófico e os cambissolos distróficos. Os latossolos ocorrem na parte superior das encostas e são solos antigos ou solos que se desenvolveram a partir de materiais intensamente intemperizados resultando em perfis profundos e bem drenados, onde a lixiviação oferece condições favoráveis para a formação de argilas de baixa capacidade de troca catiônica. A sequência de horizontes $\mathrm{A}, \mathrm{B}$ e camada $\mathrm{C}$ apresenta pouca variação morfológica ao longo dos perfis, que tem profundidade superior a 02 metros. Apresentam-se em agregados pequenos e estáveis, o que proporciona boas condições de arejamento, circulação de água e baixa susceptibilidade à erosão. Por outro lado, são pobres em nutrientes, têm acidez elevada e altos teores de alumínio trocável, apresentando potencial agrícola. São solos pouco evoluídos, ácidos e predominantemente argilosos, moderadamente drenados, de baixas fertilidades naturais e muito susceptíveis à erosão. (EIA, Estudo de Impacto Ambiental Lavrar Mineração Ltda, 2000).

\subsubsection{Recursos hídricos}

A Província da Ardósia de Minas Gerais é banhada pelos rios Pará e Paraopeba. A região apresenta uma boa disponibilidade hídrica superficial, com variação anual pouco intensa, com cheias e recessões, ás vezes, pronunciadas. A pluviosidade varia de 1000 a 1500 mm/ano. Dados da estação pluviométrica (Santa Cruz - rio Paraopeba) indicam deflúvios mensais máximos no mês de fevereiro e mínimos nos meses de agosto, setembro e outubro.

Na região, predominam aquíferos do tipo fraturado (em ardósias, calcários e ortognaisses) e cárstico (em calcários), onde a circulação e armazenamento de água estão associados à porosidade secundária, determinada por falhas e fraturas. Nos períodos chuvosos, aparecem pequenas percolações d'água nos contatos solo/ardósia e são responsável pelo surgimento de pequenas nascentes intermitentes. As infiltrações diretas são dificultadas pelo fatodas fraturas serem descontínuas e estarem preenchidas por argila. As ardósias do Supergrupo Bambuí constituem rochas com permeabilidade secundária, pouco desenvolvida, devido ao fato de se alterarem e dar origem a argilas, que poderão colmatar possíveis fraturas abertas existentes, diminuindo a capacidade de armazenamento de água. Devido a esse baixo grau de armazenamento e a transmissividade, este sistema aquífero pode ser classificado como um aquifugo. Esta reserva via de regra, é responsável pela recarrega do aquífero fraturado inferior, formado por rochas carbonáticas. Os calcários, por outro lado, podem desenvolver importante sistema aquífero, quando existe significativa diferença de cota entre a área de recarga e o nível de base regional. (EIA, Estudo de impacto ambiental Lavrar Mineração Ltda, 2000). 


\subsubsection{Cobertura vegetal regional}

A área em análise abrange o bioma denominado cerrado. Tal bioma compreende vegetação heterogênea do Planalto Central denominado complexo do cerrado, que apresenta várias formações vegetais, quais sejam: campo limpo, campo sujo, campo rupestre, cerrado, cerradão, mata ciliar e floresta estacional semidecidual. (RIZZINI, 1963).

O cerrado, no geral, compreende uma cobertura vegetal composta de árvores isoladas, baixas, tortuosas, geralmente de casca grossa, folhas grandes, coriáceas e raízes profundas. O estrato arbustivo apresenta exemplares com alturas variadas. O estrato subarbustivo-herbáceo geralmente desaparece no período de seca e reaparece no início daschuvas (BRANDÃO, 1992).

As matas ciliares presentes nas margens de rios, córregos, ribeirões e lagoas, distribuemse por algumas regiões e recebem influência florística das formações florestais próximas (MENDONÇA, 2000).

\section{MATERIAIS MÉTODOS}

Além da revisão de literatura e aquisição de dados em órgaos ambientais, e na cidade, a pesquisa consistiu-se em três etapas, sendo a primeira, a pesquisa qualitativa, através da aplicação de um questionário. Coube a segunda etapa o "Trabalho de Campo" em parceria com Escola Estadual "Renato Filgueiras" realizado num ponto do córrego da "Estribeira", e última, etapa que consistiu em acompanhar o processo de beneficiamento da ardósia da empresa Pedral Pedras, bem como em visitas a postos de saúde locais a fim de relacionar a poluição local com doenças respiratórias.

Posteriormente os questionários foram analisados visando a elaboração dos histogramas.

\subsection{APLICAÇÃO DO QUESTIONÁRIO}

O questionário anexo contem doze questões. Para caracterizar a população, as questões foram articuladas levando em consideração a denúncia ou omissão dos impactos, além de conhecimento de termos ligados ao meio ambiente e legislação. Em relação ao formato das questões, pode -se dizer que houve opção de mais de uma resposta, o que tornou o processo de análise das respostas demorado.

Os locais de aplicação do questionário, fornecido abaixo, foram escolhidos na para construir uma amostra heterogênea, portanto, escolas, comércio, faculdade, empresas tiveram a oportunidade de participar, totalizando 200 formulários preenchidos, levando em consideração a população local e uma margem de erro menor que $10 \%$. 


\subsection{TRABALHO DE CAMPO}

A segunda etapa consistiu no "Trabalho de Campo" realizado num ponto docórrego da Estribeira, em parceria com Escola Estadual "Renato Filgueiras". O córrego da Estribeira (C.E), nasce em Maravilhas, cidade vizinha de Papagaios, contorna o município e desagua no Riacho das Areias, afluente do rio Pará. O ponto escolhido para o Trabalho de campo possui as seguintes coordenadas $\left(19^{\circ} 26^{\prime} 39.9^{\prime \prime} \mathrm{S} 44^{\circ} 44^{\prime} 52.3^{\prime \prime} \mathrm{W}\right)$, sendo estas obtidas com

auxílio do Google Maps. A escolha do local foi direcionada pela intensa atividade de serraria deardósia, conforme mostra a figura 14 . A seta mostra o ponto $\left(19^{\circ} 26^{\prime} 39.9^{\prime \prime} \mathrm{S} 44^{\circ} 44^{\prime} 52.3^{\prime \prime} \mathrm{W}\right)$.

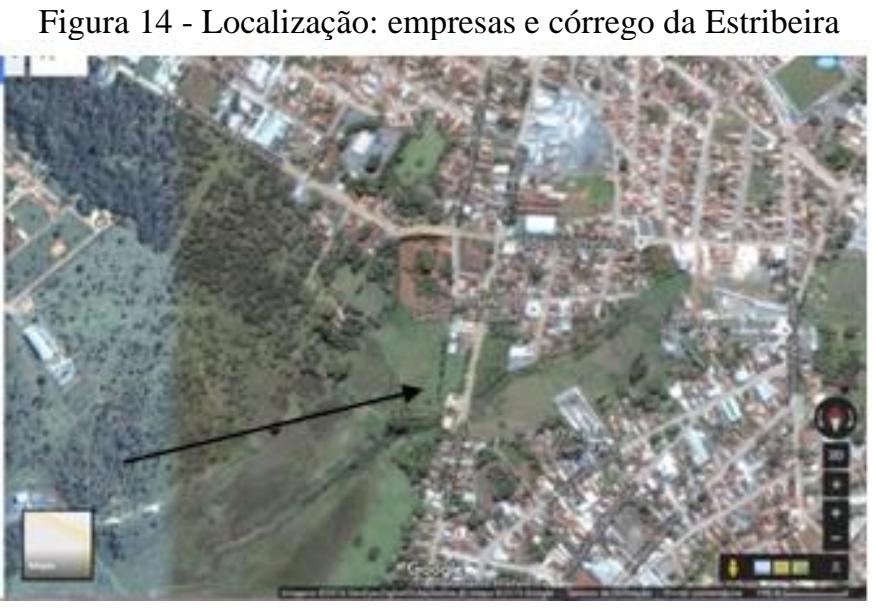

Fonte: Google Imagens

\subsection{REGISTRO DO BENEFICIAMENTO E LEVANTAMENTO SECRETARIAMUNICIPAL DE SAÚDE}

A empresa Pedral Pedras foi escolhida devido localização próxima ao córrego da Estribeira, de acordo com as figuras 15 e 16. Então, na terceira etapa, acompanhou-se o processo produtivo da industria, permitindo caracterizá-la. Trata-se de uma empresa com a produção voltada para a exportação de telhas de ardósia, que são utilizadas em larga escala em países temperados, devido à neve escoar facilmente pela superfície da ardósia. A ardósia é recebida em blocos, e é transformada em telhas e ou pisos e colocadas em caixas, numeradas e enviadas para a transportadora.

Visando a exportação, é emitida a documentação necessária, como nota fiscal, certificado de expurgo, sendo este realizado pelos armazéns localizados nos portos. A rota de exportação mais utilizada pela empresa é o Porto do Rio de Janeiro. 
Figura 15 - Localização: empresa e córrego da Estribeira

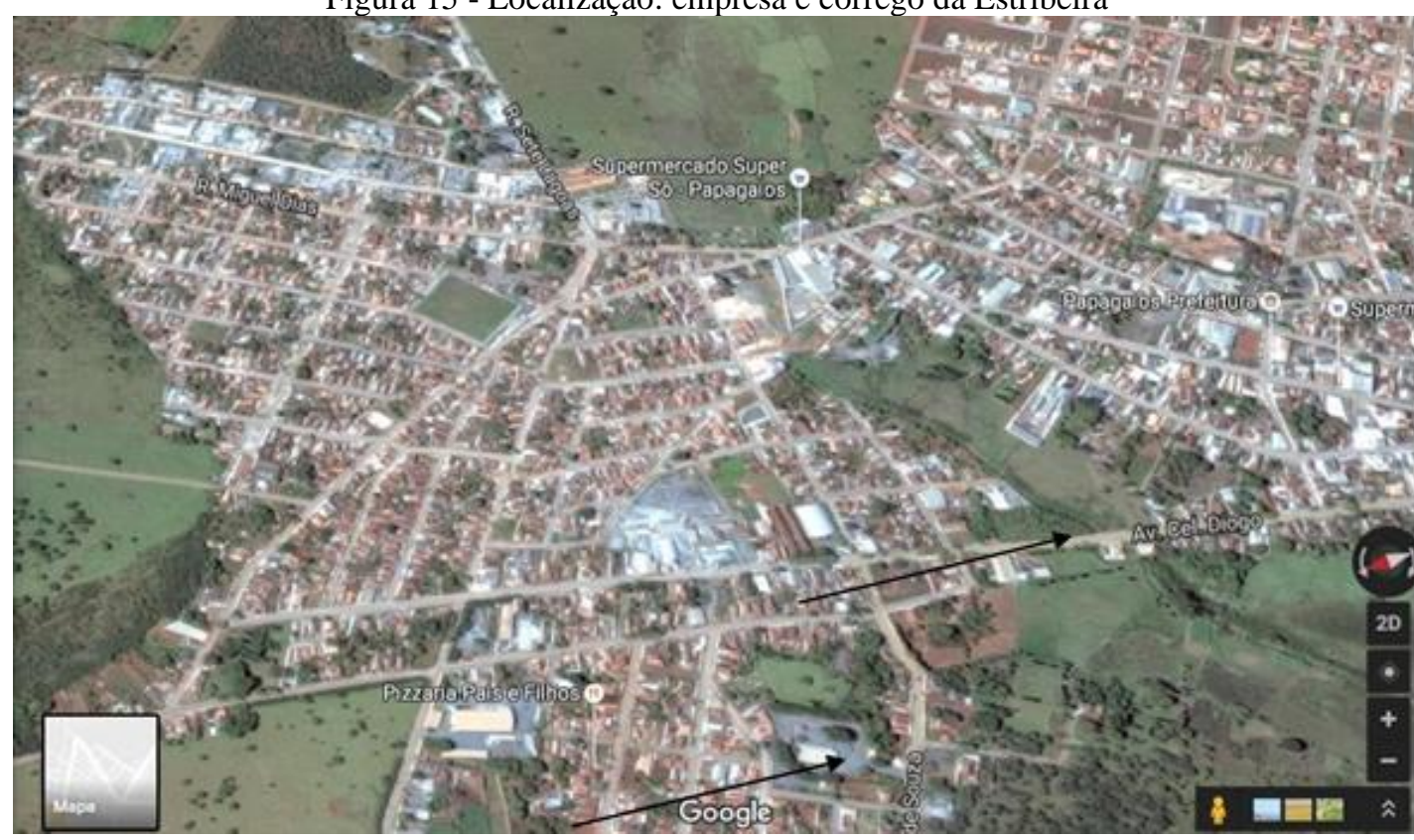

Fonte: Google Imagens

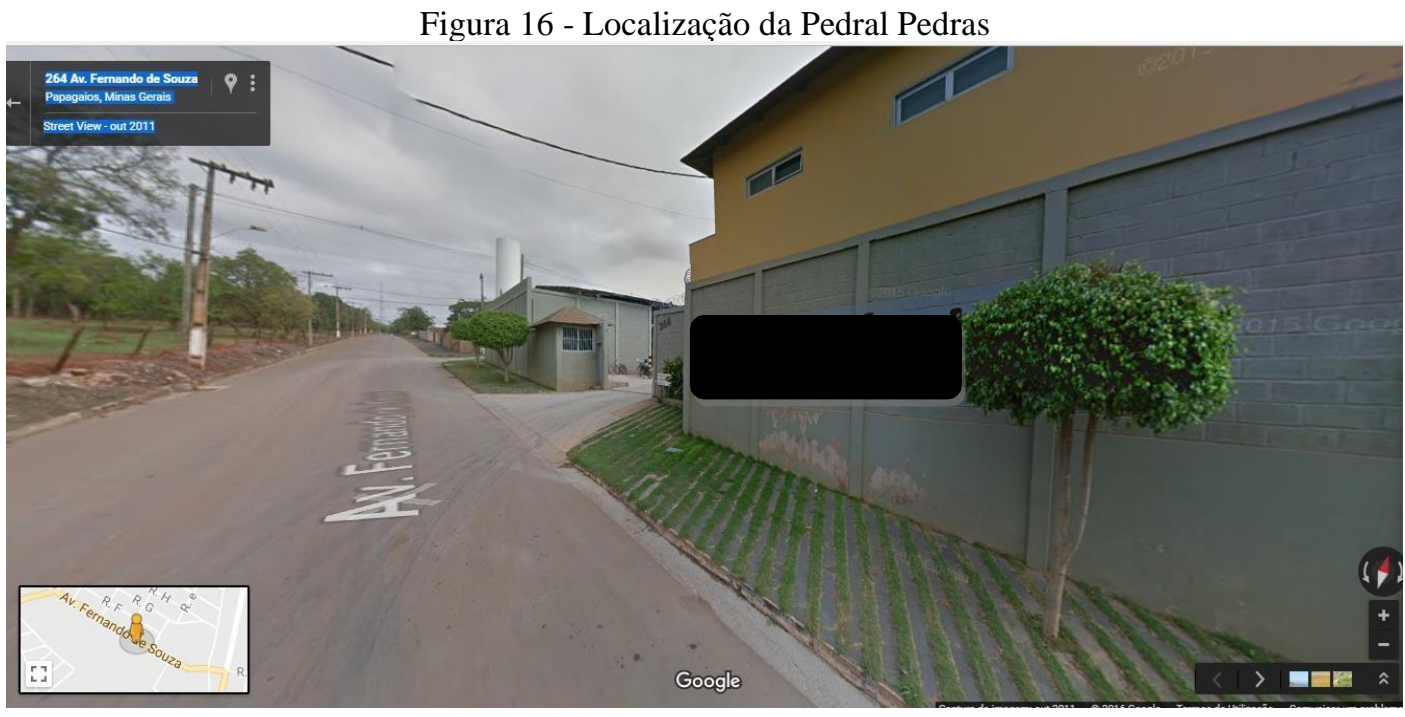

Fonte: Google Imagens

Sobre o impacto que o beneficiamento da ardósia causa sobre a saúde da população fezse um levantamento, na terceira etapa do trabalho, que consistiu em entrevistas com 4 profissionais de saúde (1 médico, 2 enfermeiras, 1 bióloga). Sabe-se que o SINAN é o Sistema de Informação de Agravos de Notificação. Neste sistema foi realizado uma pesquisa, feita pela funcionária da Secretaria de Saúde de Papagaio, conforme figura 17, visando a aquisição de dados que relacionasse a extração e beneficiamento da ardósia a quadros clínicos, sendo o seguinte quadro clínico extraído do sistema, de acordo com a figura 18. 
Figura 17- Profissional da Secretaria de Saúde

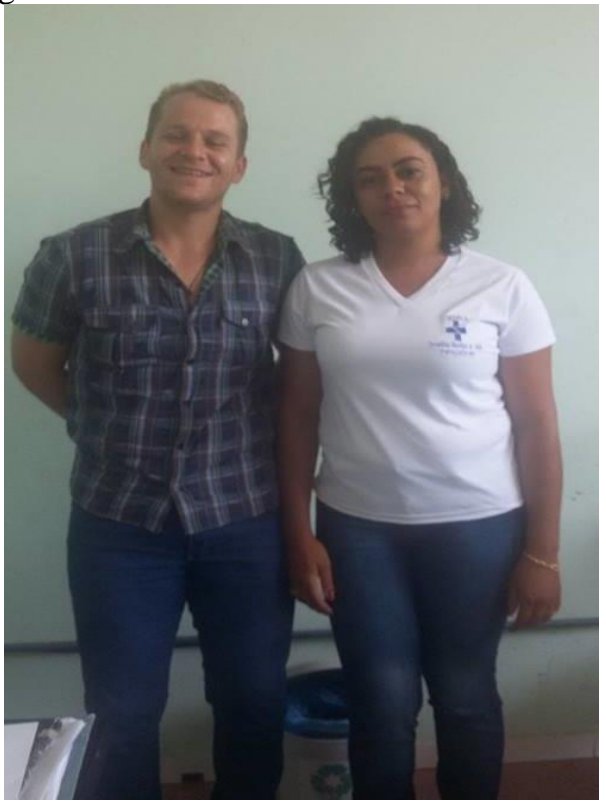

Figura 18- Quadro Clínico de paciente com CID evidenciado

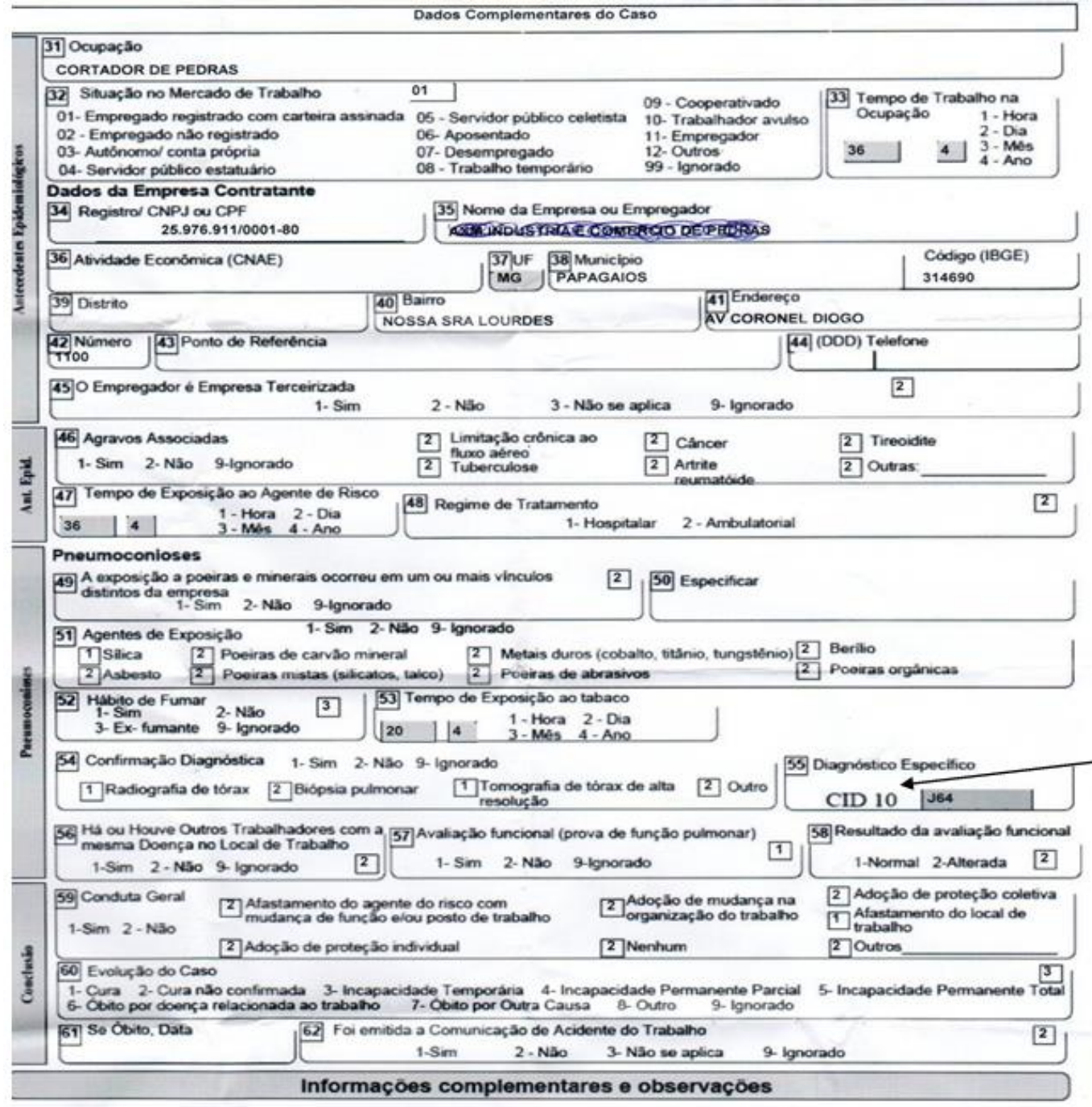

Fonte: SINAM, 2017 


\section{RESULTADOS E DISCUSSÕES}

Em relação à pesquisa feita pôde se organizar como resultado o declínio da ardósia e as alternativas para minimizar os impactos ambientais, uma vez que impactos foram denunciadose que a crise no setor de ardósias, foi constatada.

\subsection{DECLINIO DA ARDÓSIA E ALTERNATIVAS PARA MINIMIZAR OS IMPACTOS AMBIENTAIS}

A cidade de Papagaios foi afetada pela crise dos últimos anos. Segundo a AMAR, a economia da cidade que dependia da ardósia, encontra-se em déficit. Nos últimos anos, localmente foram fechadas 3,2 mil postos de trabalho dos cinco mil que existiam nas mineradoras e serradoras do município.

Em agosto de 2008, as vendas começaram a despencar. Alguns empresários do setor também suspenderam as atividades na área da mineração devido as queda nas vendas, levando a cidade a conviver, com mais frequência, com problemas de desemprego. Outros empresários do setor também suspenderam as atividades na área da mineração, devido queda nas vendas, levando ao abandono dos empreendimentos, o que caracteriza o passivo ambiental.

A figura 19, remete à questão do passivo ambiental que no caso da cidade dePapagaios. Oscilações de preços, desvalorização de moedas de importadores, levam as pequenasserrarias de ardósia ao encerramento das atividades, contribuindo para a formação do passivo ambiental. É bom ressaltar que as grandes empresas são mais visadas pelos órgãos ambientais, logo, os pequenos empreendimentos abandonados, em conjunto mostram os reflexos da crise no setor de rochas ornamentais. Numericamente não foi possível quantificar o número de empreendimentos abandonados. Embora o beneficiamento ocorra dentro da cidade, muitas pequenas empresas que foram abandonadas nunca existiram na Junta Comercial, ou no setor de alvarás da prefeitura municipal.

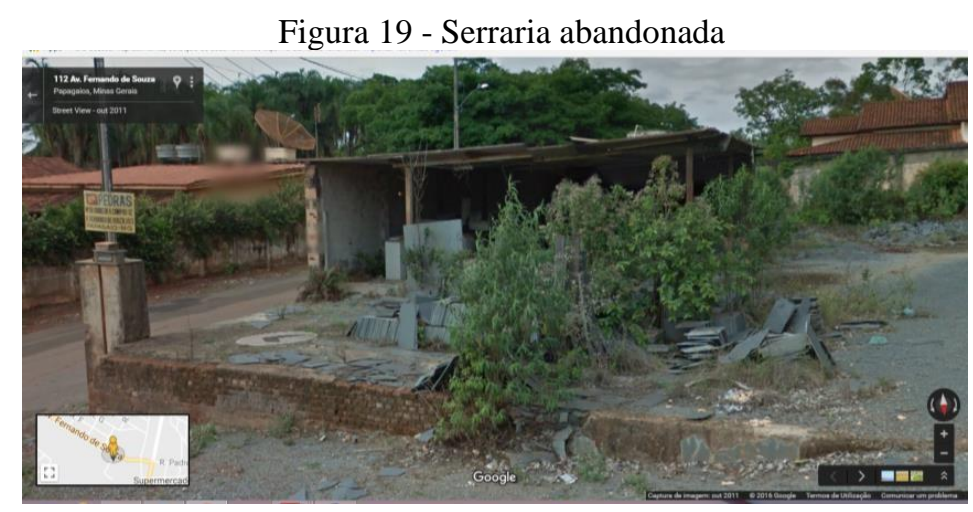

Fonte: Google Imagens 
A recuperação das áreas degradadas deve ser realizada pelos empreendedores. Cabe aos empreendimentos planejar o futuro, remediando desta maneira, possíveis situações que danifiquem o meio ambiente. (SÁNCHEZ, 2004).

A demarcação de área com objetivo de construção de um distrito industrial, feita pela FEAM, pode ser observada na figura 20. Tal distrito auxiliaria na redução de impactos visuais, diminuição de ruídos e particulados gerados localmente, além da redução de doenças respiratórias, como as detectadas na Secretaria Municipal de Saúde.

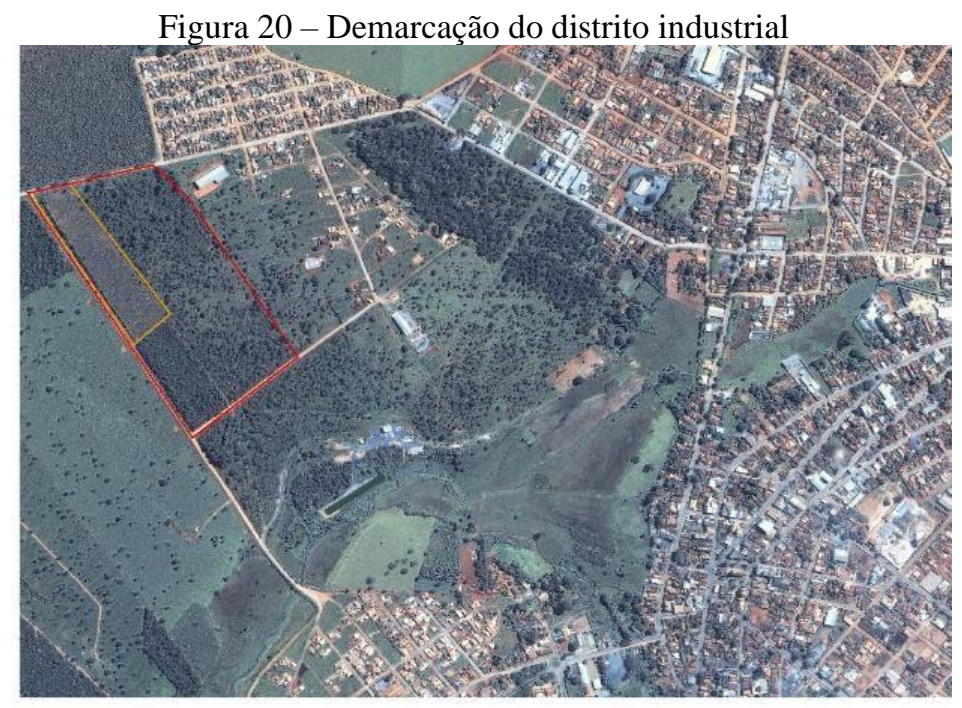

Fonte: FEAM, 2017

As grandes mineradoras possuem programas de gestão ambiental, o que não é prioridade das pequenas mineradoras. Paralelamente a este assunto, a questão do reaproveitamento dos resíduos sólidos oriundos dos processos de beneficiamento das rochas ornamentais como uma alternativa de redução do impacto ambiental, além do processo dedestinação de resíduos através da destinação dos mesmos em aterros legalizados pelos órgãos competentes. A questão dos resíduos sólidos é, atualmente, um dos temas centrais de preocupação como o ambiente, e sendo a cidade um polo industrial, consequentemente, toneladas de resíduos são produzidas e, boa parte das vezes, os mesmos são abandonados nas vias púbicas, nos córregos. (AMAR, 2017).

Os rejeitos da ardósia sob a forma de pó ou lama, oriundos do beneficiamento, apresentam propriedades cerâmicas promissoras. O pó da ardósia, por não apresentarplasticidade, deve ser misturado às argilas visando melhorias no poder de agregação. Testes realizados, especificamente para cerâmica vermelha, tem mostrado que é possível introduzir $40 \%$ de pó de ardósia (abaixo de peneira de 32 mesh) e manter a absorção d'água dentro do limite especificado pelas normas ABNT para os produtos de cerâmica vermelha além da manutenção das condições de extrusão. (OLIVEIRA, 2001) 
Numa outra perspectiva de aproveitamento, a técnica de rochagem, que atualmente é considerada uma alternativa estratégica, barata e ecologicamente correta para a restauração de solos lixiviados pode melhorar as características essenciais de fertilidade dos solos e aumentar a disponibilidade de nutrientes necessários para o desenvolvimento das de espécies do cerrado. (FREITAS, 2012).

Outra aplicação, seria através do reaproveitamento da sílica existente nos pós de ardósia, como materiais nanoestruturados que apresentam dimensões na ordem de um bilionésimo do metro $\left(1 \mathrm{~nm}=10^{-9} \mathrm{~m}\right)$. Nessa escala de tamanho, os materiais apresentam novas propriedades, antes não observadas em tamanho macroscópico, por exemplo, a tolerância à temperatura, a variedade de cores, as alterações da reatividade química e a condutividade elétrica. Uma aplicação desta tecnologia é a produção de fibras com acréscimo de nanopartículas de sílica, resultando propriedades mecânicas melhoradas como a diminuição da absorção de água, quando comparados ao polietileno (FERNANDES, 2017).

\subsection{DISCUSSÃO DOS RESULTADOS RELATIVOS AO QUESTIONÁRIO}

Como a parte metodológica do trabalho foi dividido em três etapas, optou-se por discutir separadamente cada etapa, sendo os resultados primeira etapa baseados na aplicação do questionário. As etapas seguintes ( $2^{\mathrm{a}}$ etapa e $3^{\mathrm{a}}$ etapa), que equivalem ao Trabalho de Campo e Acompanhamento processo produtivo da "Pedral Pedras" e visita à Secretaria Municipal de saúde foram discutidas respectivamente nos tópicos 4.3 e 4.4 .

A discussão feita neste tópico é relativa ao tratamento das informações extraídas das respostas do questionário aplicado em Papagaios, MG.

Como resultado da aplicação do questionário, ( $1^{\text {a }}$ etapa do trabalho), o histograma I, mostra que houve a predominância do ensino médio.

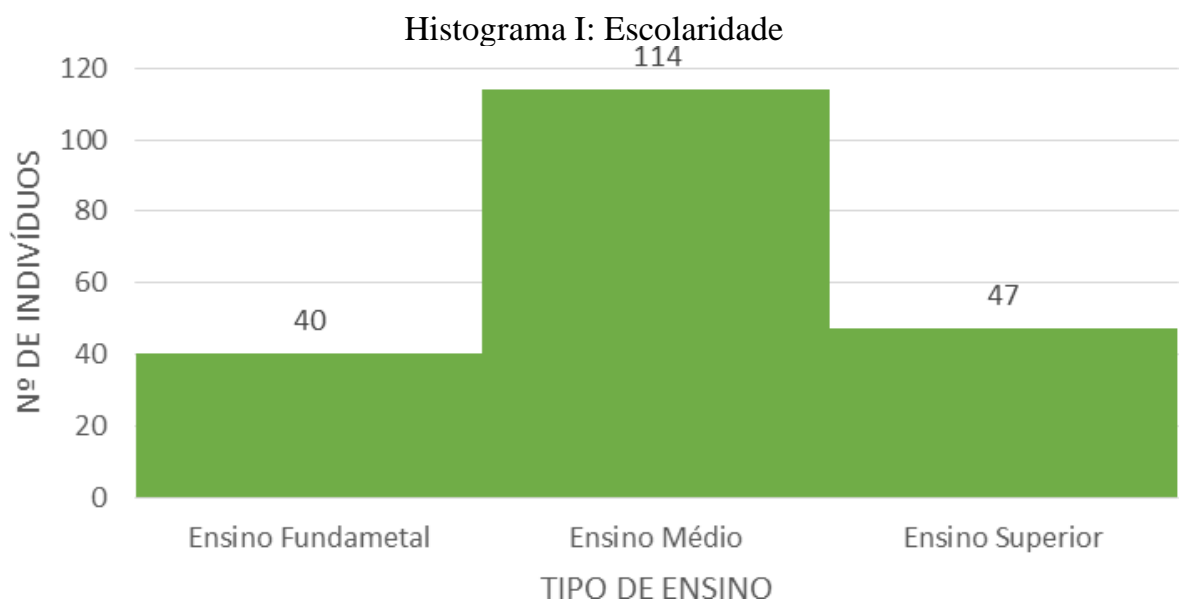


Uma porcentagem significativa (179 pessoas) sabe que a extração, dependendo de como é gerenciada pode degradar o meio ambiente, informação obtida no histograma II. Provavelmente os impactos visuais direcionaram as respostas. Como pôde ser visto nas figuras anteriormente mostradas $(8,9)$, os impactos da extração são visualmente identificáveis, fato que pode ter influenciado no tipo de resposta afirmativa.

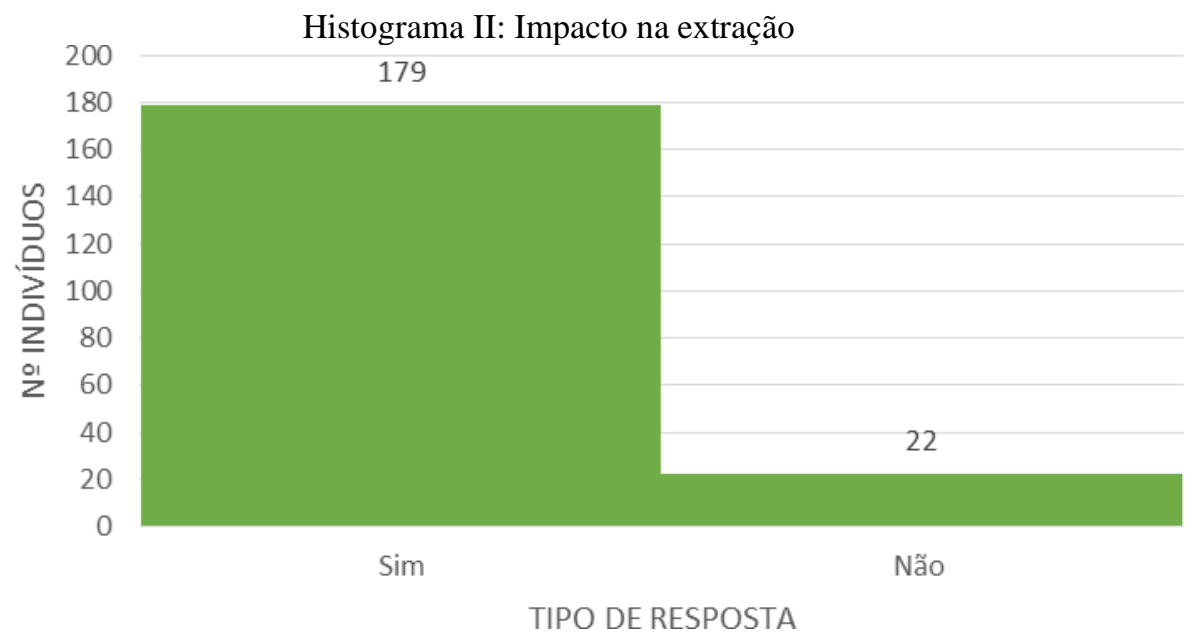

O histograma III mostra que a população denuncia os impactos ambientais na cidade, levando a degradação do meio ambiente, fato aceito por $97,5 \%$ da população amostral. A diferença entre a interpretação dos histograma II e III é relativamente pequena, uma vez que no histograma III, o teor das respostas é local. Porém acredita-se que ocorreu uma associação primeiramente na escala local para posterior associação entre os impactos na extração de uma maneira geral.

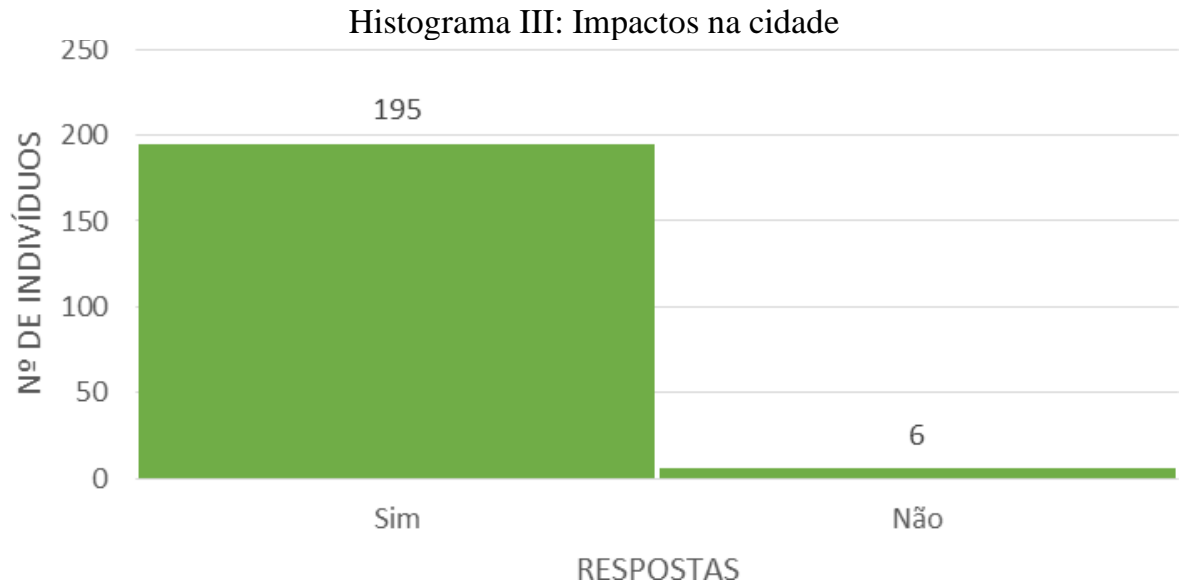

O histograma IV mostra que a comunidade percebe que outras medidas em relação ao beneficiamento da ardósia deveriam ser tomadas, uma vez que a mudança de trajeto durante o 
transporte dos "lajões" não soluciona todos os problemas ambientais da cidade. O histograma IV está relacionado a figura 32, encontrada no anexo deste trabalho. Trata-se de uma placa que proíbe a circulação de caminhões em algumas vias da cidade. A medida é racional uma vez que os caminhões podem danificar a infraestrutura urbana, além de aumentarem os riscos de acidentes envolvendo queda de carga. Por outro lado, a medida não é suficiente, uma vez que naspróximas questões do questionário serão apresentados outros impactos ambientais.

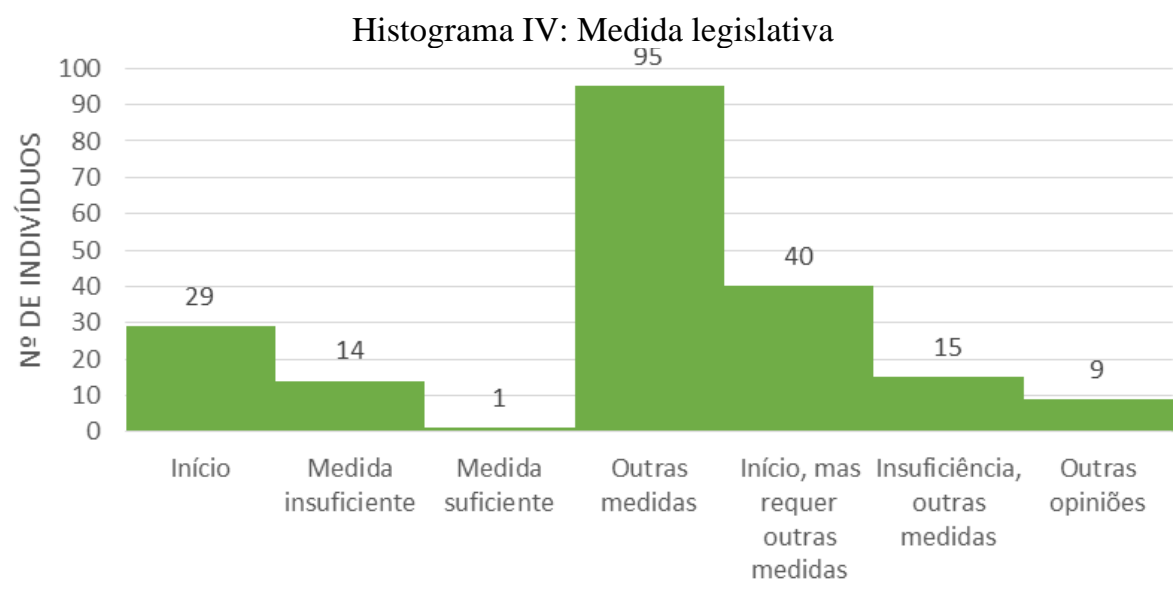

SENSAÇÕES DA AMOSTRA

A população considera-se desinformada e desconhecedora das leis ambientais, sendouma parcela significativa diz não conhecer integralmente a legislação, de acordo com ohistograma V. Este fato pode ser associado a interrupção de processos de licenciamentoambiental ou de autorização para funcionamento, uma vez que a figura 12, mostra uma página dosite do Sistema Integrado de Informações Ambientais, com procedimento ambiental incompleto. Muitos empreendimentos apenas preenchem o FCE, que é o formulário de CaracterizaçãoIntegrada, portanto não cumprem todas as etapas para conseguir uma autorização defuncionamento ou a licença.

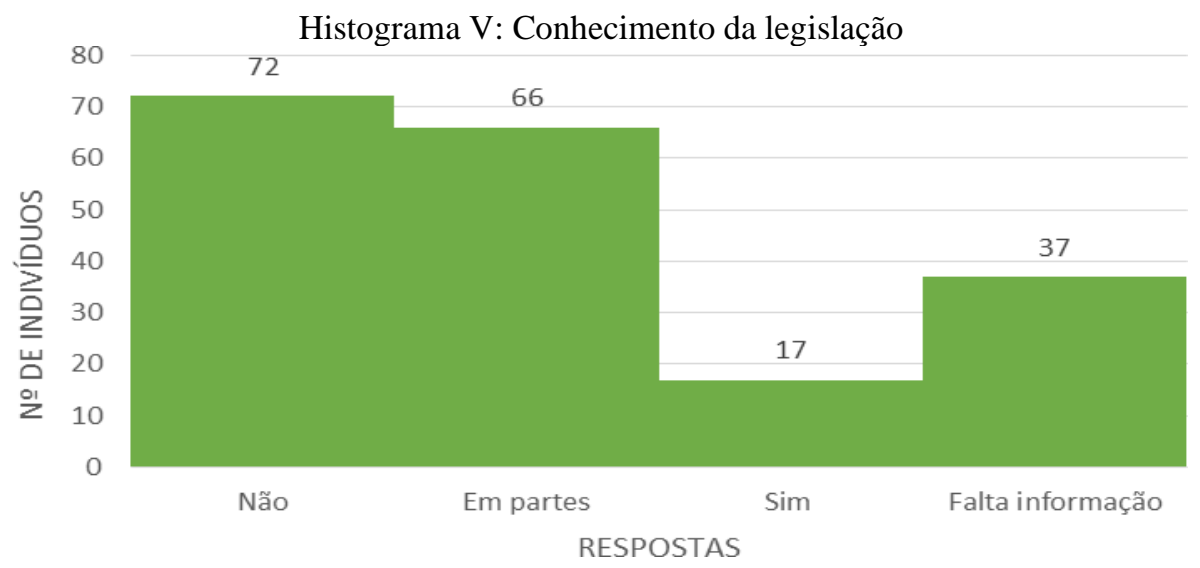


A partir da análise do histograma VI, percebe-se que a falta de informação a respeito do tema, faz com que não ocorra o engajamento em campanhas de educação ambiental. A situação da relação econômica com a extração/ beneficiamento, se não trabalhada de maneira correta pode contribuir para a criação de uma situação de negligência em relação aos efluentes gerados e aos impactos causados na cidade, uma vez que são fontes de renda. Os números de casos de silicose fornecidos pela Secretaria de Saúde, são baixos levando em consideração as conversas com profissionais de saúde. Por outro lado, é compreensível a situação, embora a postura não seja correta e a população denunciar o lançamento de efluentes e estar sensibilizada pela causa ambiental local.

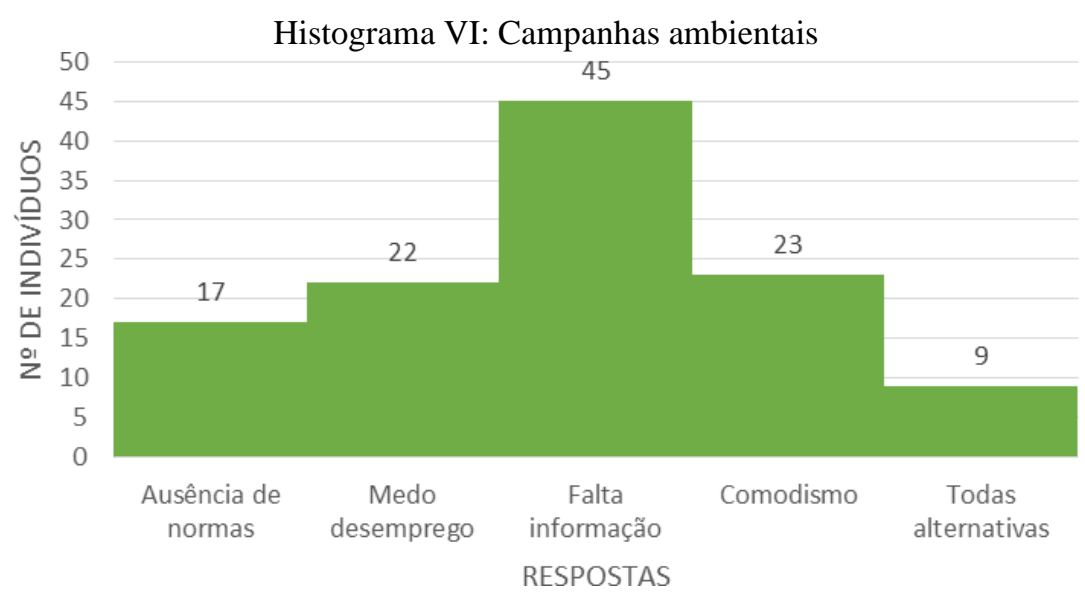

A partir da análise do histograma VII, percebe-se que maioria significativa da população denuncia o lançamento de efluente nos cursos d'água da cidade. Como discutido nos histogramas II e III, e a partir da figura 10, no corpo do respectivo trabalho, pode-se dizer que os efluentes são lançados na água, fato diagnosticado pelos moradores, portanto, é comprensível a denúncia do lançamento dos efluentes.

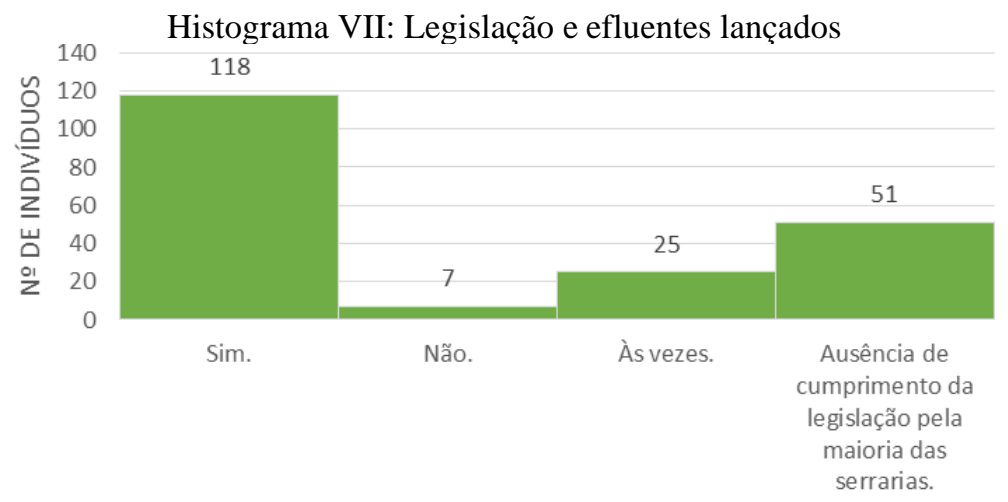

RESPOSTAS 
Informações do histogramas anteriores mostram que a comunidade denuncia osimpactos ambientais locais. No histograma VII percebe-se que a população acredita der possível a mudança do quadro ambiental da cidade, fato considerável. A partir do teor das respostas, podese ver que a população se encontra sensibilizada pela causa ambiental local. Caso optassempela não necessidade de mudança o quadro de suspeita de negligência seria confirmado de maneira global. Uma parcela pequena é descrente, uma vez que segundo esta parcela, a mudança seria possível a partir do cumprimento da legislação.

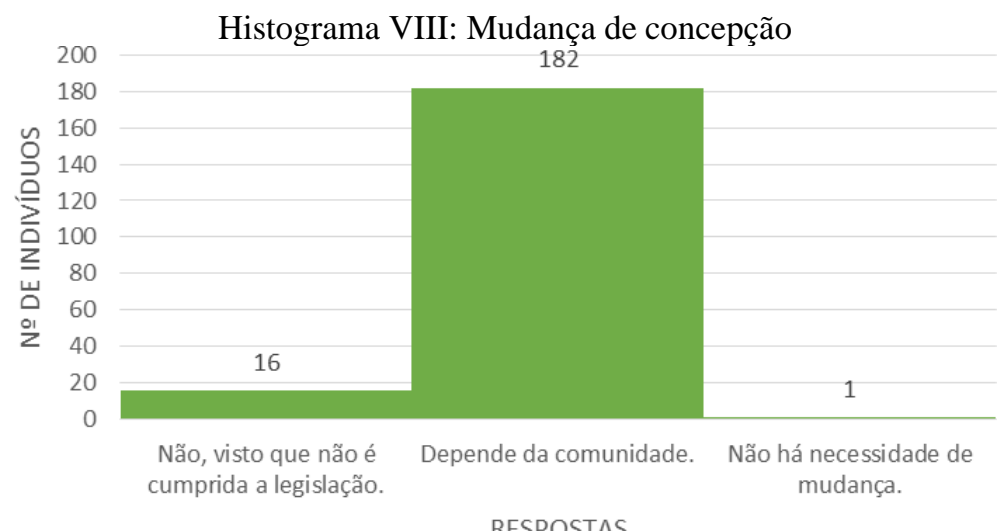

O histograma IX é importante, pois pode-se fazer um parelelo à questao econômica da cidade. Boa parte da população depende da extração e beneficiamento da ardósia, fato que, de certa forma, dificulta a discussão da situação de maneira clara. Na verdade, a populaçao se encontra dividida em relaçao à discussão do problema. Como mencionado anteriormente, acredita-se que a economia local tenha ligação com a discussão do problema, embora a discussão do problema de maneira correta, poderia render finaceiramente para a populaçao, uma vez que a discussão traz inovações, ideias empreendedoras e tentativas de agregar valor, por exemplo, aos resíduos.

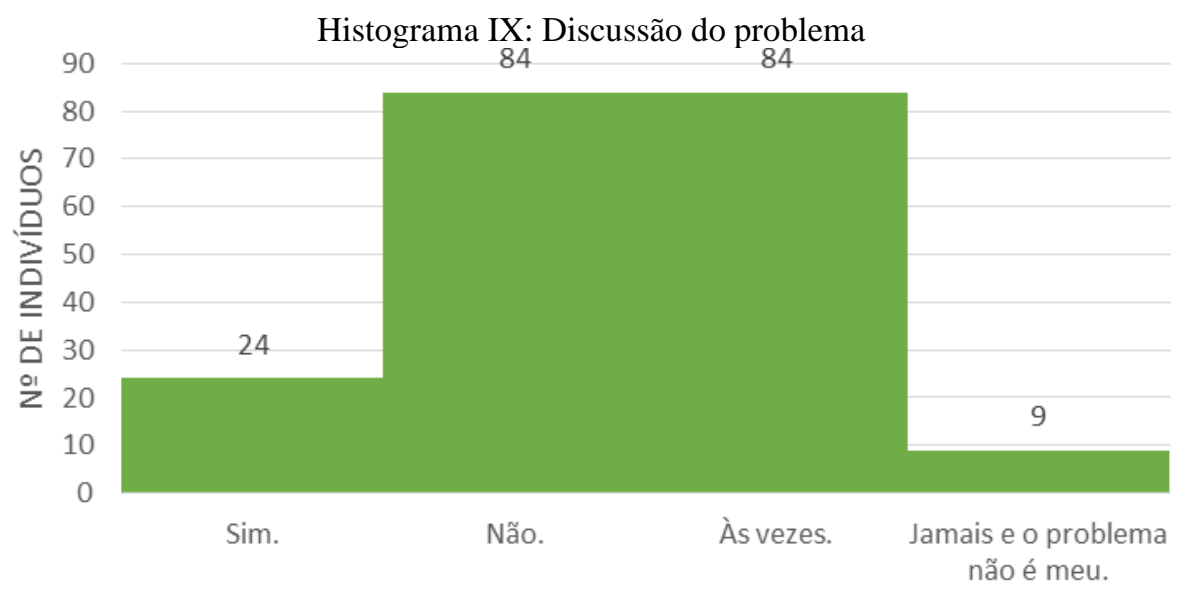


O histograma $\mathrm{X}$ nos mostra que a há necessidade de um díalogo entre poder público, empreendedores e comunidade, para que a conscientização e a redução dos impactos seja concretizada. Mais uma vez as respostas majoritárias mostram que a população clama por conscientização, uma vez que vê seu local degradando e perdendo valor natural e financeiro. Um centro de educação ambiental local, seria uma referência para a cidade, uma vez que a população reconheça a importância do aspecto conscientizador. O caráter punitivo e objetivos sem práticas são quase desprezados. Em relação aos objetivos sem prática, acredita-se que não houve a compreensão correta do termo.

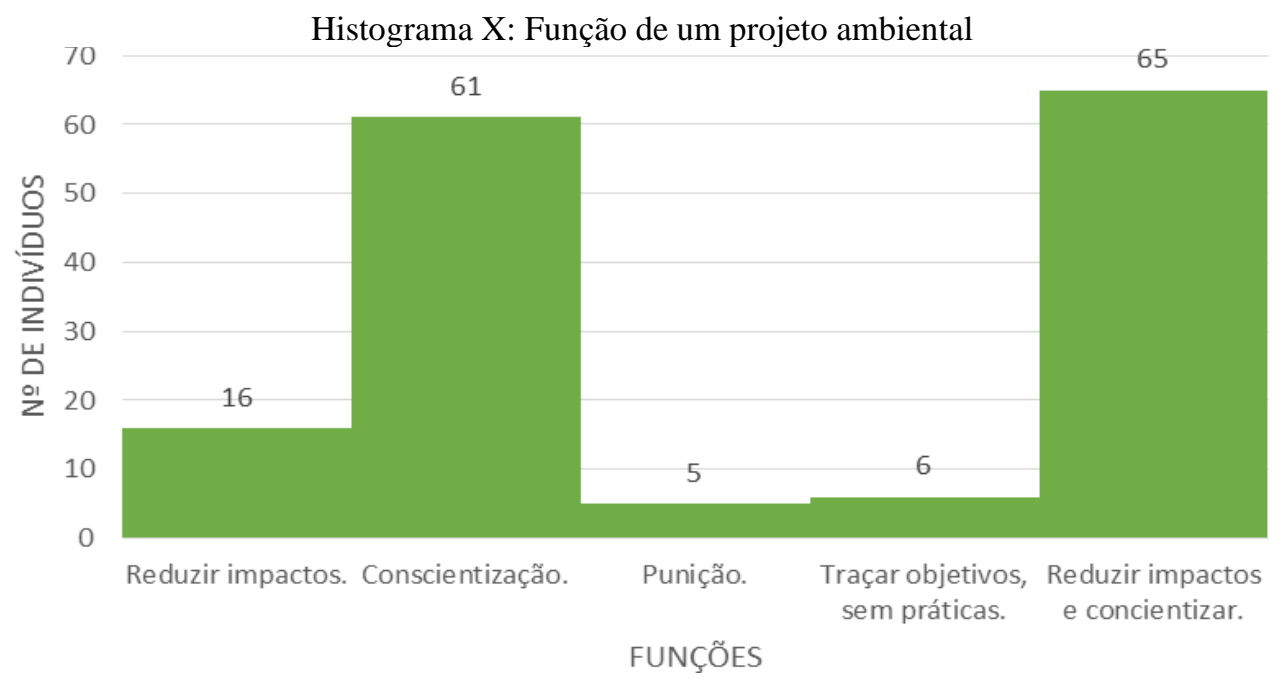

O histograma XI nos mostra que a o termo sustentabilidade é desconhecido pela maioria. É bom se ressaltar que o termo sustentabilidade é complexo, e no caso específico da cidade de Papagaios, a sustentabilidade seria adquirida a partir do momento em que a cidade conseguisse extrair e beneficiar a ardósia, atendendo as necessidades locais, levando em consideração a minimização dos impactos ambientais. Não seria sustentável, por exemplo, uma situação envolvendo a proibição de uso de um recurso local, sendo que a população dependesse do mesmo para abastecimento das reais necessidades básicas. Portanto, embora não consigam caracterizar a prática sustentável, os pedidos por conscientização, a denúncia dos impactosambientais, nesta linha de raciocínio, é uma atitude sustentável. 


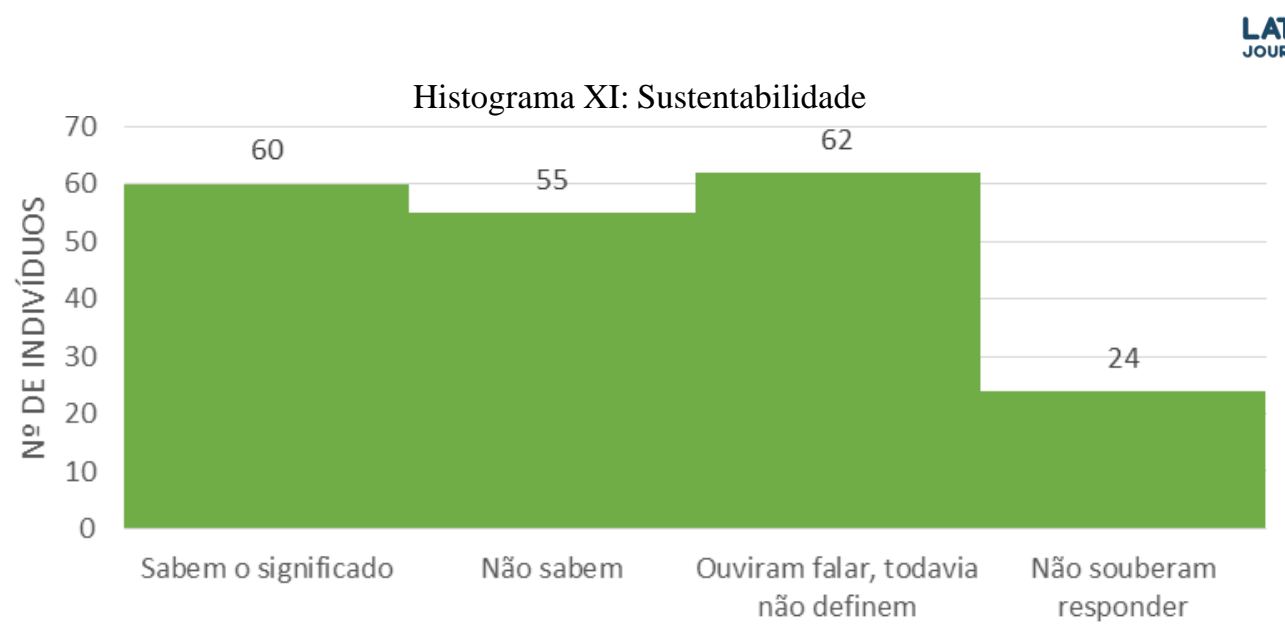

RESPOSTAS

O histograma XII, nos mostra os tipos de impactos, segundo a população amostral, existentes na cidade. Pela análise gráfica, percebe-se a denúncia de vários problemas, sendo o lançamento de efluentes comprovados pelo registro fotográfico a seguir, obtidos em parceriacom alunos da escola Estadual "Renato Figueiras". Reforça-se aqui a ideia que na mineração, devido aos tipos de resíduos gerados os impactos ambientais visuais são marcantes. No caso das serrarias de ardósia, os ruído produzidos no beneficiamento também são consideráveis, uma vez que em Papagaios, o mesmo é feito dentro da cidade, fato que leva a população a associar outros impactos como: o risco de acidentes, além das doenças respiratórias.

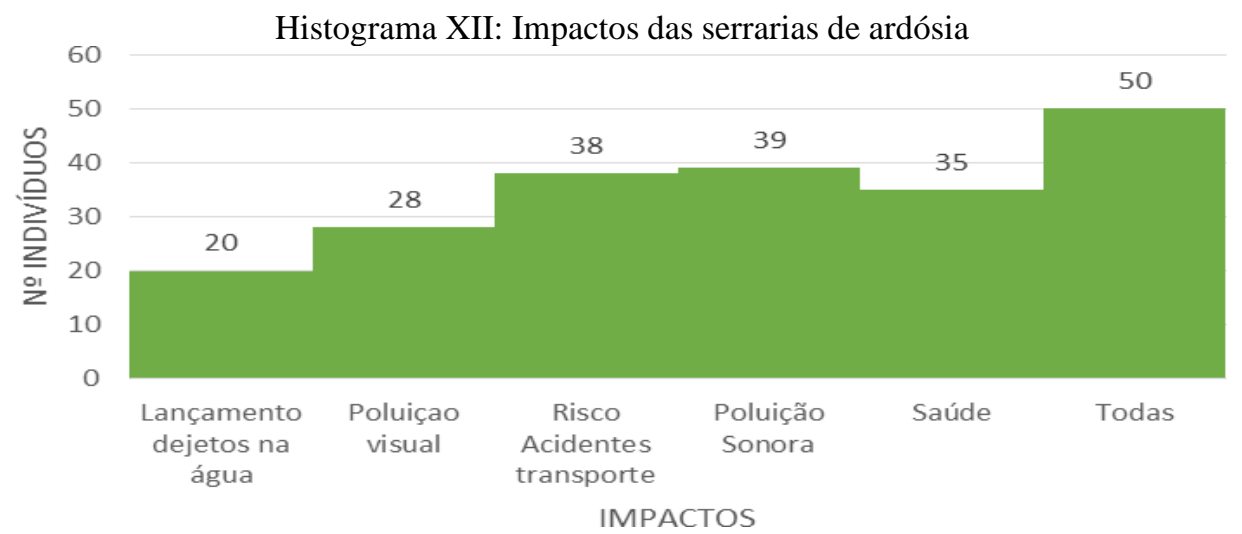

\subsection{DISCUSSÃO DOS RESULTADOS RELATIVOS TRABALHO DE CAMPO}

O Córrego da Estribeira recebia, conforme registro fotográfico, efluentes industriais do tipo pó de ardósia, além de resíduos de origem doméstica (plásticos, garrafas, entre outros), que, possivelmente, foram abandonados ou trazidos pela corrente de água, de acordo com as figuras $(21,22,23,24,25)$ “A olho nu”, não foi possível o caracterização de material biológico.

A concentração de serrarias de ardósia localizadas próximas ao Córrego da Estribeira contribui para o lançamento de resíduos neste, uma vez que as serrarias de ardósia ao 
negligenciarem o procedimento de licenciamento ambiental ou a autorização de funcionamento não cumprem as condicionantes exigidas pelos órgãos ambientais.

A questão da sensibilização em relação a causa ambiental pôde ser vista. Muitos alunos se sensibilizaram em relação ao problema do acréscimo dos efluentes nas águas do Córrego da Estribeira, mostrando-se indignados logo cobraram posturas das autoridades.

Figura 21 - Efluentes C.E

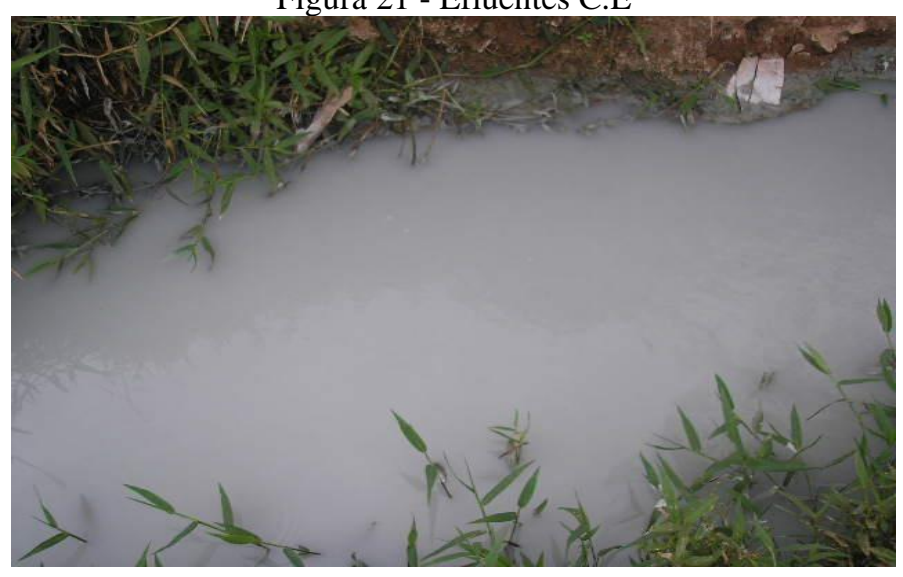

Figura 22 - Registro de efluentes no C.E.

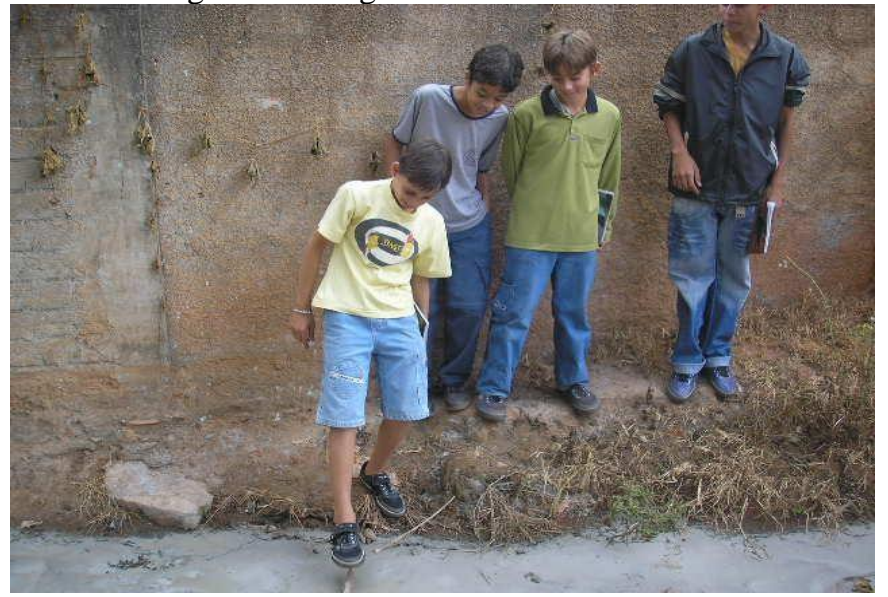

Figura 23 - Registro de efluentes carreado para C.E.

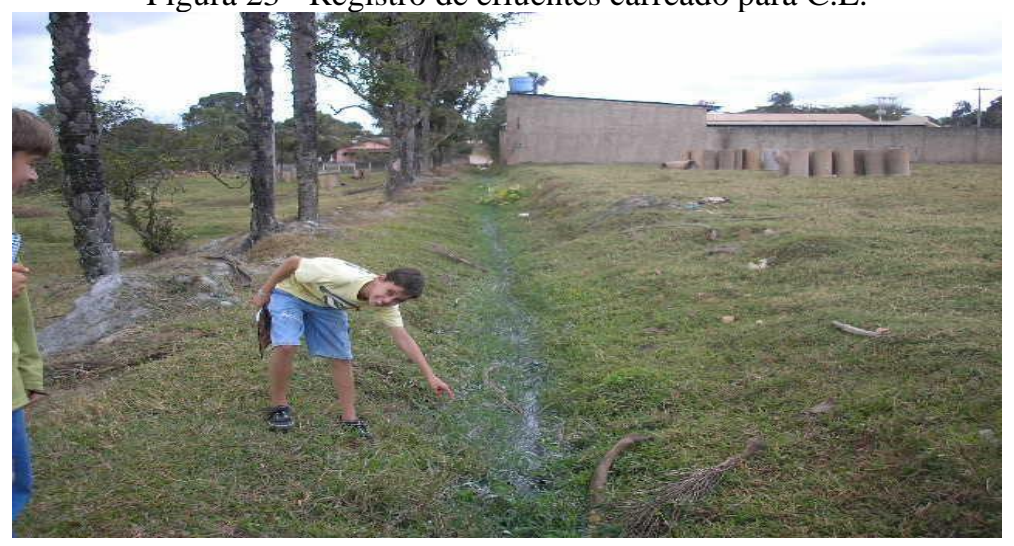


Figura 24 - Registro de efluentes carreado para C.E.
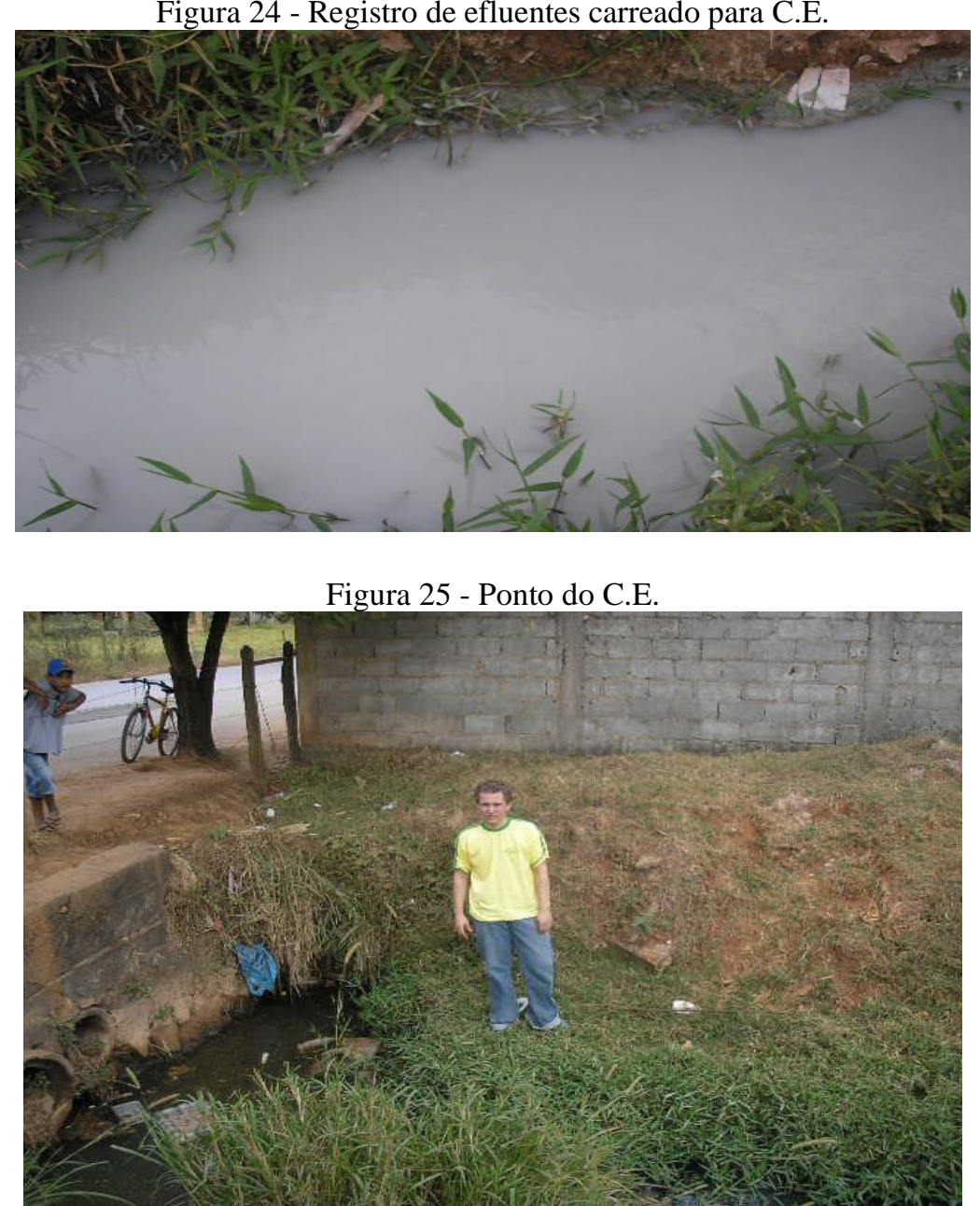

\subsection{DISCUSSÃO DOS RESULTADOS RELATIVOS REGISTRO DO BENEFICIAMENTO E} LEVANTAMENTO SECRETARIA MUNICIPAL DE SAÚDE

O processo produtivo da Pedral Pedras, pôde ser visto logo. Os efluentes gerados na refrigeração dos equipamentos, mediante o processo produtivo, circulam através de canais, caindo num sistema de caixas separadoras de resíduos, e através do bombeamento, a água retorna ao galpão a fim de ser reutilizada. Os resíduos sólidos com granulometria maior são transformados em brita, processo não ocorrido no interior da empresa. Abaixo, as figuras (26, 27,28, 29, 30, 31) caracterizam o beneficiamento da ardósia, linha produtiva e resíduos.

Embora a empresa Pedral Pedras esteja localizada nas proximidades do Córrego da Estribeira, não houve relação direta entre o efluente e a empresa. O sistema de caixas separadoras de efluentes industrias mostradas nas figuras: 30 e 31 são responsáveis pela criação do reciclo de resíduos que além de economizar água, e a retenção do efluente internamente, evitando a poluição das águas e solo locais. 
Figura 26-Beneficiamento da ardósia

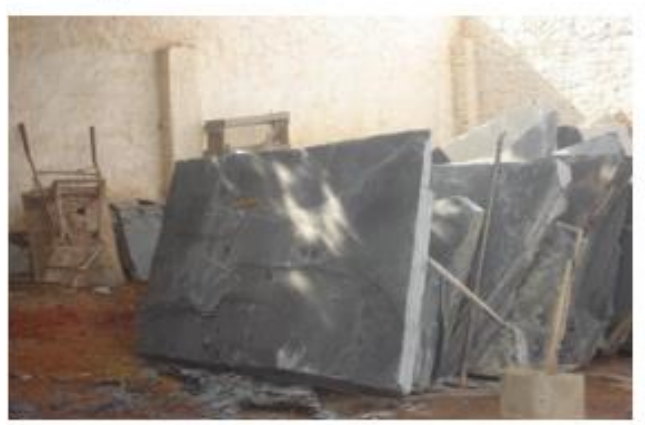

Figura 28 - Telha para Exportação

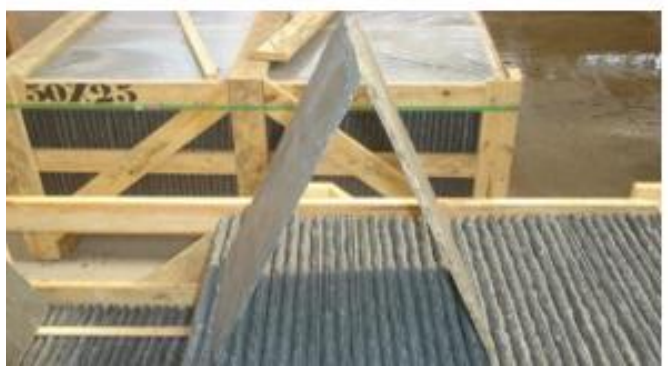

Figura 30 - Caixa separadora de efluentes

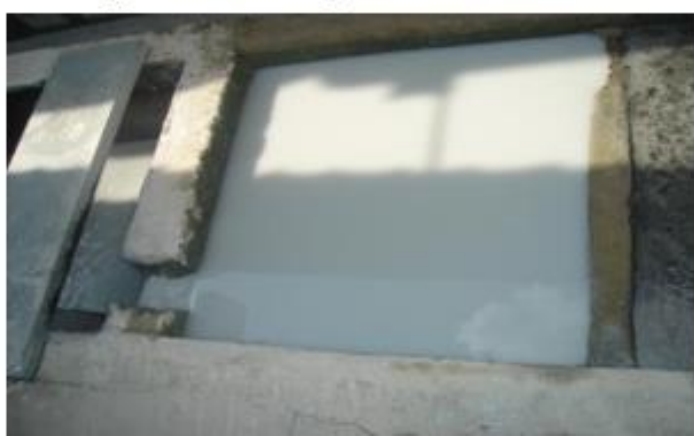

Figura 27 - Beneficiamento da ardósia

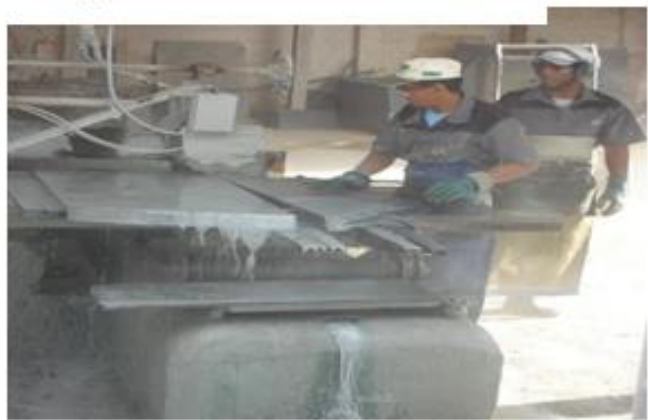

Figura 29 - Beneficiamento e Efluentes

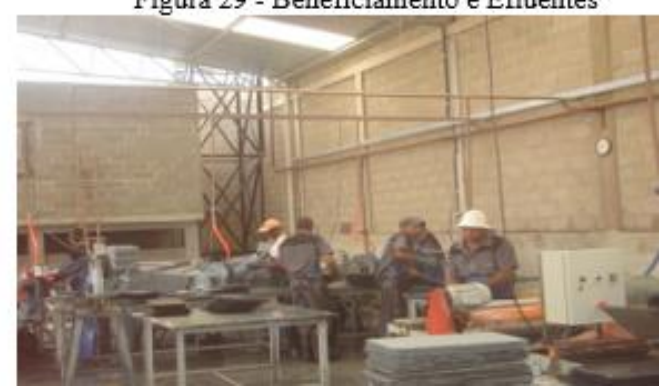

Figura 31 - Sistema de Sep. de Efluentes

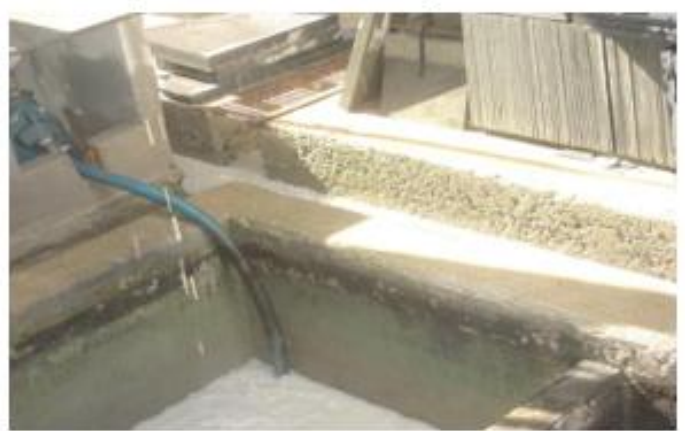

Quanto ao levantamento na Secretaria Municipal de Saúde, o CID CLASSIFICAÇÃO INTERNACIONAL DE DOENÇAS), 10J64, diagnostica um indivíduo como portador da pneumoconiose não especificada, que é causada pela inalação de poeiras inorgânicas, geralmente associada a trabadlho em metalúrgicas, construtoras, mecânicas ou minas. As variantes incluem a antracose ou "pulmão negro", causada pela poeira de carvão, a asbestose - por poeira de asbesto, a silicose ou "doença do esmeril" causada por poeira de sílicae a Fibrose de bauxita por poeira de bauxita. A beriliose é causa pela inalação da poeira de berílio, a siderose ou "pulmão de soldador" pela poeira de ferro e, a bissinose pela poeira de algodão enquanto a siderossilicose causada por um misto de poeira contendo sílica e ferro.

O uso dos equipamentos de proteção individual é obrigatório pela legislação, emboraseja comum o não uso do mesmo. Além disso, o equipamento protege o indivíduo mais próximo ao pó da ardósia, que recebe maior incidência dos particulados. Uma vez que os particulados se 
difundem na atmosfera, em épocas frias, principalmente aumentam-se os quadros de alergias, que também podem ter uma relação ao processo de beneficiamento

Em relação aos casos de silicose, a princípio em conversa com o médico plantonista da Unidade de Saúde Central de Papagaios, pôde perceber a existência de um número maior de casos distribuídos várias Unidades de Saúde dos bairros. Houve investigação, sem êxito.

Embora os funcionários agissem de acordo com o Código de Ética profissional, ou seja, o tratamento cordial foi mantido durante todas as visita, as expectativas durante os retornos ao locais para aquisição de dados, boa parte das vezes, não eram alcançadas. Os números de casos reduziam ou até mesmo eram considerados inexistentes. Não foi liberado pela enfermeira chefe os prontuários dos pacientes, que a princípio seria, logo, houve o direcionamento para o SINAN, que é abastecido pelos funcionários da Secretaria de Saúde local que tem autonomiapara não notificarem os casos ocorridos, embora a postura não seja considera ética, porém, é uma possibilidade.

\section{CONCLUSÃO}

A pesquisa mostra que a população não se encontra omissa em relação aos impactos ambientais oriundos da extração e beneficiamento da ardósia, entretanto, a discussão do assunto, na comunidade, ainda não ser consenso. Embora a parcela amostral estivesse financeiramente ligada ao processo de beneficiamento da ardósia, houve a denúncia a partir do questionário, dos problemas ambientais, confirmado através de registro fotográfico e sensorial (poluição visual, sonora, lançamento de efluentes nas vias públicas e cursos d’água, risco de acidentes no perímetro urbano) que foram apontados como consequências do beneficiamento da ardósia.

Além da denúncia dos impactos ambientais, percebe-se que a população pede por medidas significativas, visando, desta maneira, a resolução dos problemas, ou seja a população encontra-se sensibilizada aos problemas relacionados ao beneficiamento da ardósia. Embora se encontre desinformada e desconhecedora das leis ambientais, acredita que a legislação não é cumprida na íntegra. A questão da falta da informação se relaciona aos processos analisados, com documentações incompletas no SIAM (Sistema de informações ambientais). As empresas, que atualmente não existem mais, funcionaram, por um bom tempo, sem as licenças específicas para o funcionamento dos empreendimentos.

A realização da pesquisa pôde mostrar, também, a dificuldade de compreensão do termo sustentabilidade, embora a população tente apoiar projetos com cunho de educação ambiental. As denúncias de impacto ambientais, na primeira etapa da pesquisa, vão de encontro àsituação do Córrego da Estribeira, que recebe efluentes industriais. 
Não há relação entre o efluente encontrado no Córrego da Estribeira e a empresa,cujo processo produtivo foi acompanhado em virtude do manejo dos resíduos. Outras empresas nos arredores provavelmente lançam os efluentes no córrego.

Através do Sistema de Notificação de doenças do Sistema Único de Saúde, há casos de doenças respiratórias provenientes do contato com a atividade mineradora e beneficiadora.

A atividade de extração e beneficiamento da ardósia encontra-se em crise, sendo possível o registro empreendimentos abandonados, caracterizados na prática como passivo ambiental. Tal crise trouxe desemprego e problemas sociais, como a violência, fato vivenciado localmente. As técnicas de adição do pó de ardósia, rochagem, e aplicação em nanomateriais são alternativas de reutilização de resíduos, mostrando que, na literatura, há vários trabalhos na área, inclusive em Papagaio.

\section{AGRADECIMENTOS}

Agradeço, primeiramente a Deus: pela renovação da minha fé, em momentos difíceis durante pesquisa, escrita e outros, sendo ELE fonte das minhas: resistência e resiliência. Posteriormente, deixo o meu muito obrigado, a minha orientadora: Profa. Dra. Alessandra Mendes Carvalho Vasconcelos, por acreditar na ideia e orientar-me. Não poderia esquecer dos meus familiares pela vezes que estive ausente em momentos necessários, nem da cidade de Papagaio, especificamente do cenário empresarial, da população amostral da pesquisa da secretaria de saúde, da Escola Estadual Renato Filgueiras e dos contadores locais de histórias enfim um agradecimento fraterno a todos que de forma direta ou indireta contribuíram para realização deste estudo. 


\section{REFERÊNCIAS}

ANDRADE, R. O. B. de; TAKESHY, T.; CARVALHO, A. B. de. Gestão Ambiental: Enfoque Estratégico Aplicado ao Desenvolvimento Sustentável. São Paulo: Makron Books, 2002.

AMAR. ASSOCIAÇÃO DE MINERADORES DE ARDÓSIA DE MINAS GERAIS. Disponível em < http://www.amarmg.com.br/ >. Acesso em: 12 fev. 2017.

BARBIERI, J. C. Gestão Ambiental Empresarial: conceitos, modelos e instrumentos. SãoPaulo: Saraiva, 2006.

BARbosA, A. L. M. Curso de Petrologia - I. Minerais petrográficos, II. Petrografia macroscópica Ouro Preto: Escola de Minas e Metalurgia - UFOP, 1974, 248 p.

BRANDÃO, M.; GAVILANES, M. L. Espécies arbóreas padronizados do cerrado mineiro esua distribuição no Estado. Informação Agropecuária, 1992.

BRASIL. Constituição (1988). Constituição da República Federativa do Brasil: lei $n^{\circ}$ 6.938, de 31 de agosto de 1981. Disponível em: <http://www.bvambientebf.uerj.br/arquivos/edu_ambiental/popups/lei_federal.html>.

essoem: 12 fev. 2017.

BRASIL. Constituição (1988). Constituição da República Federativa do Brasil: lei no 9.605,de 12 de fevereiro de $1998 . \quad$ Disponível em:

<http://www.planalto.gov.br/ccivil_03/leis/L9605.htm>. Acesso em 12 fev. 2017.

CHIODI FILHO, C.; RODRIGUES, E. P.; ARTUR, A. C. Ardósias de Minas Gerais, Brasil: características geológicas, petrográficas e químicas. Geociências. São Paulo, UNESP, v.22, n.2, p.119-127, 2003.

CHIODI FILHO, C.; RODRIGUES, E.ARTUR, A. C. Panorama Técnico Econômico do Setor de Rochas Ornamentais no Brasil. In: REPOSITÓRIO INSTITUCIONAL DA UNIVERSIDADE ESTADUAL PAULISTA. Rio Claro: Instituto de Geociências e Ciências Exatas. Geociências. São Paulo, v. 23, n. 1/2, p. 5-20, 2004. Disponível em: $<$ http://repositorio.unesp.br/bitstream/handle/11449/106896/ISSN1980-900X-2004-231-5-20.pdf? sequence $=1 \&$ isAllowed $=\mathrm{y}>$. Acesso em:

CHIODI FILHO, C. Evolução do setor de rochas ornamentais e o parque de beneficiamento. Revista Pedras do Brasil, v. 32, p. 44-52, nov., 2004 (d).

CONSELHO NACIONAL DO MEIO AMBIENTE. Resolução $n^{\circ}$ 001, de 23 de janeiro de 1986.Diário Oficial da União, Poder Executivo, Brasília, DF, 17 de fev. 1986. Disponível em: <http://www.mma.gov.br/port/conama/res/res86/res0186.html>. Acesso em: 12 fev. 2017.

CONSELHO ESTADUAL DE POLÍTICA AMBIENTAL. Resolução n ${ }^{\circ}$ 74, de 2004. Minas Gerais, MG. Disponível em: <http://www.igam.mg.gov.br/images/TR_outorga/dn_copam_7404\%20empreendimentos\%20pol uidores.pdf>. Acesso em: 12 fev. 2017. 
DECRETO 45986

http://www.lexml.gov.br/urn/urn:lex:br;minas.gerais:estadual:decreto:2012-05-23;45968.

Acesso12/02/2017.

DONAIRE, D. Gestão Ambiental na Empresa. 2.ed. São Paulo: Atlas, p.49-1999.

FEAM- FUNDAÇÃO ESTADUAL DO MEIO AMBIENTE. Disponível em < http://www.feam.br>. Acesso: 12 fev.2017

FERNANDES, Janaina Rodrigues. Nanopartículas de sílica sinalizada como compatibilizanteem compósitos de fibras de sisal/polietileno. Polímeros, São Carlos, 2017.

FERREIRA, H. S.; RANGEL, M. C. Nanotecnologia: aspectos gerais e potencial de aplicaçãoem catálise. Química Nova, v.32, n.7, p.1860-1870, 2009.

FREITAS, V. L. O. Restauração de áreas degradadas pela extração de ardósia, utilizando seus rejeitos, no município de Papagaio, Minas Gerais. 2012. 130p. Tese (Doutorado em Ecologia, Conservação e Manejo de Vida Silvestre) - Instituto de Ciências Biológicas, Universidade Federal de Minas Gerais, Belo Horizonte, 2012.

INSTITUCIONAL. Principais fontes de atividades de Papagaios - MG. Disponível em: <http://www.papagaios.mg.gov.br/detalhe-da-materia/info/principais-fontes-deatividades-de-papagaios---mg/16605>. Acesso em 12 fev. 2017.

MEIO, B. B. Influência da flora das florestas Amazônica e Atlântica na vegetação do cerrado sensu stricto. Revista Brasil. São Paulo, v.26, n.4, p.437-444, dez. 2003.

MENDONÇA, M. P.; LINS, L. V (Orgs.) Lista vermelha das espécies ameaçadas de extinçãoda flora de Minas Gerais. Belo Horizonte: Fundação Biodiversitas, 2000.

MINAS GERAIS (Estado). Lei $\mathrm{n}^{\mathrm{o}}$ 14.940, de 29 de dezembro de 2003. Minas Gerais, BeloHorizonte, $30 \quad$ dez. $2003 . \quad$ Disponível em: <http://www.fazenda.mg.gov.br/empresas/legislacao_tributaria/leis/114940_2003.htm>. Ac essoem: 12 fev. 2017.

MINAS GERAIS (Estado). Regularização Ambiental. Secretaria de Estado de Minas Gerais, MG. Disponível em: <http://www.meioambiente.mg.gov.br/regularizacao-ambiental>. Acessoem: 02 nov. 2016.

OLIVEIRA, M. C. A.; RODRIGUES, E. P. Aproveitamento de rejeitos da mineração ebeneficiamento de ardósia na fabricação de cerâmica vermelha para construção civil. In: ANAIS DO 45 CONGRESSO BRASILEIRO DE CERÂMICA. Florianópolis, jun., 2001. Não

paginado.

PARENTI COUTO, J. G. Nota sobre a estratigrafia do Grupo Bambuí, na região de Felixlândia, Minas Gerais. Revista Brasileira de Geociências, v. 10, n. 4, p. 292-296, 1980. 
REDCLIFT, M. Wasted Couting the Cost of Global Consumptin. London: Earthscan Publicatinons, p. 5,1996.

RELATÓRIO FINAL. Gestão de Passivos Ambientais na Mineração: plano de ação para a sustentabilidade do setor de rochas ornamentais - ardósia, Papagaios. Belo Horizonte: Fundação Estadual do Meio Ambiente, 2014 Disponível em: $<$

http://www.feam.br/images/stories/arquivos/producaosustentavel/plan\%20acao_rochas_orna mentais_ardosia.pdf>. Acesso em 12 fev. 2017.

RIZZINI, C. T. A flora do Cerrado: análise florística das savanas centrais. In: SIMPÓSIO SOBRE O CERRADO, 3, São Paulo. Anais... São Paulo: Edusp, 1963, p.126-177.

RIZZINI, C. T. Tratado de fitogeografia do Brasil: aspectos sociológicos e florísticos. Hucitec.São Paulo, Edusp, v.2, 1979

ROSA, João Guimarães. Grande sertão: veredas, 19a ed. Rio de Janeiro, 2001, p. 08.

SALES, Miguel. Lei de crimes ambientais. Jus Navigandi Teresina. 2, 24, abr/1999. Disponívelem <http:/www1.just.com.br/doutrina/texto.asp?id=1706>. Acesso em 25/01/2016

SÁNCHEZ, L. E. Avaliação de impacto ambiental: conceitos e métodos. 2.ed. São Paulo: Oficina de textos, 2013.

SEMAD- SECRETARIA DE ESTADO DE MEIO AMBIENTE E DESENVOLVIMENTO SUSTENTÁVEL. Disponível em < http://www.meioambiente.mg.gov.br>, Acesso: 12 fev.2017

SISTEMA DE INFORMAÇÃO DE AGRAVOS DE NOTIFICAÇÃO. Portaria n $^{\circ}$ 204, de 17 de fevereiro de 2016. Minas Gerais, MG. Disponível em: <http://www.portalsinan.saude.gov.br>.Acesso em: 12 fev. 2017.

SISTEMA INTEGRADO DE INFORMAÇÃO AMBIENTAL. Estudo de Impacto Ambiental Fazenda Funil, Papagaio, MG, SIAM, 2000.

SISTEMA INTEGRADO DE INFORMAÇÃO AMBIENTAL. Disponível em < Disponível em < http://www.meioambiente.mg.gov.br>. Acesso: 12 fev.2017 


\section{ANEXO A}

\section{QUESTIONÁRIO PROJETO PESQUISA: OS IMPACTOS DO BENEFICIAMENTO DA ARDÓSIA} EM PAPAGAIOS, MG.

1- Qual a suaescolaridade?

( ) Ensino Fundamental

( ) Ensino Médio

( ) Ensino Superior

2- A extração de recursos naturais leva a degradação do ambiente?() Sim

( ) Jamais

( ) Às vezes

3- Na sua cidade, a extração da ardósia, bem como o beneficiamento da mesma, gera algum impacto ambiental?

() $\mathrm{Sim}$

() Não

4- No caso específico das serrarias de ardósia, quais seriam os principais problemas resultantes do processo de beneficiamento da ardósia?
( ) Lançamento de dejetos nas águas.
( ) Poluição visual
( ) Risco de acidentes ao transportar "matações" pelas vias urbanas.
( ) Todas as alternativas descritas acima.

5- Apesar das leis que proíbem o transporte de cargas de ardósia por algumas vias da cidade, conforme figura 32, estar em fase de adaptação, você acha que tais medidas são suficientes?
( ) Pode se considerar um início
( ) A medida é insuficiente
( ) A medida é suficiente
( ) Outras medidas poderiam ser tomadas

Figura 32- Placa proibição de trajeto de veículo

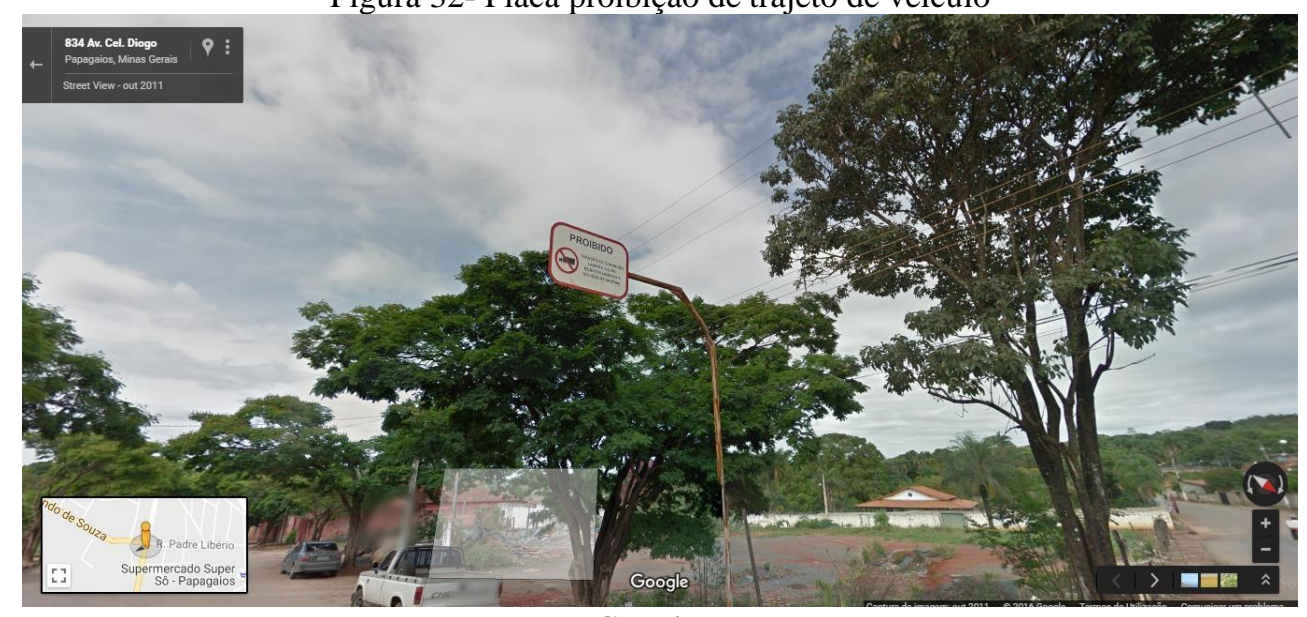

Fonte: Google Imagens 
6- Você tem conhecimento a respeito das normatizações, bem como das leis aplicadas aoprocesso de exploração e beneficiamento da ardósia?
( ) Não
( )Empartes
() $\mathrm{Sim}$
( ) Falta informação

7- Em sua opinião, quais seriam os motivos da população não participar de campanhas de educação ambiental?
( ) Inexistência das mesmas
( ) Medo de desemprego
( ) Falta de informação
( ) Comodismo.

8- Você já ouviu falar em desenvolvimento sustentável?() Sim e sei o que isto significa
( ) Não
( ) Já ouvi, mas não consigo definir
( ) Não sei responder

9- É possível, mudarmos a situação ambiental da nossa cidade?() Sim, mais isto não é importante

( ) Não, visto que falta o comprimento da legislação() Depende dos esforços de toda comunidade

( ) Não precisamos de mudarmos pois a situação é boa

10- Mesmo com a legislação que considera obrigatório o tratamento dos efluentes industriais, há descarga de resíduos de ardósia nos córregos da cidade?
( ) $\mathrm{Sim}$
( ) Não
( ) Às vezes
( ) Falta cumprimento da legislação pela maioria das serrarias de ardósia.

11- Em sua opinião, o assunto é discutido abertamente nas escolas, nas igrejas e em outras instituições?
( ) Sim
( ) Não
( ) Às vezes
( ) Jamais, visto que isto não é problema meu

12- Projetos ambientais, para você, apresentam quais dos seguintes objetivos?

( ) Visar ao uso de técnicas e outras ferramentas que reduzam o impacto sobre os recursos utilizados

( ) Promover a conscientização, mediante ao uso dos recursos de forma sustentável() Punir através das sanções

( ) Traçar apenas objetivos, sem uso de metodologias eficazes de funcionalidade 